\title{
Conifer proportion explains fine root biomass more than tree species diversity and site factors in major European forest types
}

\author{
Leena Finér ${ }^{\mathrm{a}, *}$, Timo Domisch ${ }^{\mathrm{a}}$, Seid Muhie Dawud ${ }^{\mathrm{b}}$, Karsten Raulund-Rasmussen ${ }^{\mathrm{b}}$, \\ Lars Vesterdal $^{\mathrm{b}}$, Olivier Bouriaud ${ }^{\mathrm{c}}$, Helge Bruelheide ${ }^{\mathrm{d}, \mathrm{e}}$, Bogdan Jaroszewicz $^{\mathrm{f}}$, Federico Selvi ${ }^{\mathrm{g}}$, \\ Fernando Valladares ${ }^{\mathrm{h}, \mathrm{i}}$
}

a Natural Resources Institute, Finland, Yliopistokatu 6, FI-80100 Joensuu, Finland

b Department of Geosciences and Natural Resource Management, University of Copenhagen, Rolighedsvej 23, 1958 Frederiksberg, Denmark

${ }^{\mathrm{c}}$ Faculty of Forestry, Stefan cel Mare University of Suceava, Romania

d Martin Luther University Halle-Wittenberg, Institute of Biology/Geobotany and Botanical Garden, Am Kirchtor 1, D-06108 Halle (Saale), Germany

e German Centre for Integrative Biodiversity Research (Div) Halle-Jena-Leipzig, Deutscher Platz 5e, D-04103 Leipzig, Germany

f Białowieża Geobotanical Station, Faculty of Biology, University of Warsaw, Sportowa 19, 17-230 Białowieża, Poland

${ }^{g}$ Department of Agrifood Production and Environmental Sciences (DISPAA), Laboratory of Applied and Environmental Botany, University of Florence, Italy

h Department of Biogeography and Global Change, National Museum of Natural Sciences, MNCN, CSIC, Serrano 115 bis, 28006 Madrid, Spain

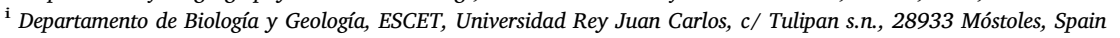

\section{A R T I C L E I N F O}

\section{Keywords:}

Carbon stock

Fine root biomass

FunDivEUROPE

Ground vegetation

soil C:N ratio

Tree species richness

\begin{abstract}
A B S T R A C T
Fine roots (diameter $\leq 2 \mathrm{~mm}$ ) contribute significantly to the forest carbon cycle and are essential for resource acquisition from the soil. We conducted a study to assess the relationships between tree and ground vegetation fine root biomass and tree species diversity (monocultures compared to 2-5 species mixtures), conifer proportion and other site factors (stand basal area, soil carbon stocks and C:N ratio) in the six major European forest types, boreal forest in Finland, temperate forests in Poland, Germany and Romania, thermophilous deciduous forests in Italy, and Mediterranean forests in Spain. We sampled the fine roots of trees and ground vegetation to the depth of $20 \mathrm{~cm}$ in the mineral soil and allocated the fine root biomass to individual tree species using near-infrared reflectance spectroscopy (NIRS). We did not find any general positive effects of tree species diversity on the fine root biomass of trees or ground vegetation across the forest types and tree species combinations. However, our results suggest that tree fine root biomass increases with tree species diversity in pure broadleaf forests, but not in pure conifer forests. Species diversity explained $7 \%$ of the variation in tree fine root biomass in the broadleaf stands. The narrow tree species diversity gradient (1-2 species) in the conifer forests compared to the broadleaf forests $(1-4)$ may have decreased the probability of conifer species combinations with below-ground functional traits conducive to over-yielding. Some evidence of diversity-mediated changes in the vertical rooting patterns of broadleaf trees and ground vegetation were found within the entire organic and $0-20 \mathrm{~cm}$ mineral soil layer although the weighted mean depth of fine root biomass was not affected. Negative diversity effects were found in the organic layer and positive diversity effects in the $0-10 \mathrm{~cm}$ mineral soil layer for broadleaf tree fine root biomass. Diversity effects were negative for ground vegetation fine root biomass in the $0-10 \mathrm{~cm}$ mineral soil layer. There was a general positive effect of conifer proportion on total fine root biomass in the organic layer, but not in the mineral soil layers. In general conifer proportion and site factors explained more of the variation in tree fine root biomass than tree species diversity. More research covering the annual variation in fine root biomass and deeper soil layers is needed before recommending managing species-rich forest for increasing below-ground biomass and carbon pools.
\end{abstract}

\section{Introduction}

Forest ecosystems are important in the global carbon (C) cycle and for maintaining terrestrial biodiversity. They account for $80 \%$ of all above-ground organic C and $40 \%$ of all soil organic C (Dixon et al., 1994). Fine roots are major contributors of C input to soil (Jackson et al., 1997; Clemmensen et al. (2013). Recently, Dawud et al. (2017) reported higher soil C stocks in more species-diverse forest stands,

\footnotetext{
* Corresponding author.

E-mail address: leena.finer@luke.fi (L. Finér).
} 
which emphasized the need to understand whether increasing tree species diversity contributes to soil $\mathrm{C}$ sequestration through belowground biomass and production (Thoms et al., 2010; Vesterdal et al., 2013; Sun et al., 2017).

Species diversity may increase ecosystem productivity (overyielding) by complementarity and/or selection effects (Loreau and Hector, 2001). Complementarity occurs when the combination of different species allows niche partitioning above- and/or below-ground and accordingly a more efficient use of light and/or soil resources or when the interactions between species are positive (i.e. facilitation) (Loreau et al., 2001; Hooper et al., 2005). In the case of fine roots niche partitioning of species can result from combining tree species with different resource-absorption efficiencies (Liu et al., 2015), different vertical rooting patterns (Büttner and Leuschner, 1994; Hendricks and Bianchi, 1995, Bolte and Villanueva, 2006), ability to grow roots deeper in soil (Brassard et al., 2013; Dawud et al., 2016) or increased filling of soil space by fine roots (Bolte and Villanueva, 2006; Brassard et al., 2011, Brassard et al., 2013; Sun et al., 2017), and thereby increasing the use of soil resources in mixtures. An increase in species number may also enhance the probability of selecting species with high overall biomass production (selection effect) (Loreau et al., 2001; Tobner et al., 2016). These species identity effects can increase fine root productivity even more than tree species diversity effects (Lei et al., 2012a; Jacob et al., 2013; Domisch et al., 2015; Lübbe et al., 2015). In the study of Domisch et al. (2015) in young European forest plantations conifer fine root biomass and production were higher than those of broadleaf species. That could be related to the lower soil nutrient availability in conifer stands indicated by lower soil C:N ratio (Cools et al., 2014; Dawud et al., 2017), and thus to the need to allocate more biomass in fine roots in nutrient poor conditions (Finér et al., 2007; Helmisaari et al., 2007). In addition to diversity and identity effects other stand characteristics, soil properties and climatic conditions affect fine root productivity and these relationships have been studied in European forests (Finér et al., 2007; Helmisaari et al., 2007; Lehtonen et al., 2016) and other geographic areas (Finér et al., 2011; Wu et al., 2015). Fine root biomass has been shown to increase with stand basal area, age and soil C:N ratio in European forests (Finér et al., 2007; Helmisaari et al., 2007; Lehtonen et al., 2016), but the relationship between fine root biomass and mean annual temperature and precipitation has not been significant (Finér et al., 2007). The relative importance or interactions of stand characteristics, soil properties and climatic conditions have rarely been addressed in relation to tree species diversity or identity.

The number of studies on the relationships between tree species richness or diversity and fine root biomass or fine root biomass production are still limited and the results are inconsistent. Reported relationships were positive (Schmid, 2002; Meinen et al., 2009a; Brassard et al., 2011, Brassard et al., 2013; Laclau et al., 2013; Bu et al., 2017; Ma and Chen, 2017; Sun et al., 2017), insignificant (Hendricks and Bianchi, 1995; Schmid and Kazda, 2002; Bauhus et al., 2000; Meinen et al., 2009b, Meinen et al., 2009c; Jacob et al., 2010, Jacob et al., 2013; Brassard et al., 2013; Lei et al., 2012b; Domisch et al., 2015; Ma and Chen, 2017) or negative (Bolte and Villanueva, 2006). The more numerous studies between tree species diversity and above-ground biomass and biomass production of trees show more consistent positive diversity effects (Zhang et al., 2012; Gamfeldt et al., 2013; Vilà et al., 2013; Ratcliffe et al., 2015; Toïgo et al., 2015; Wu et al., 2015; Jucker et al., 2016; Liang et al., 2016; Pretsch and Schütze, 2016), suggesting that tree species diversity effects on above-ground biomass or productivity are not necessarily mirrored by tree fine root productivity
Table 1

Characteristics of the study sites (MAT $=$ mean annual temperature; MAP $=$ mean annual precipitation).

\begin{tabular}{llllll}
\hline Site & $\begin{array}{l}\text { Latitude, } \\
\text { longitude }\end{array}$ & MAT, ${ }^{\circ} \mathrm{C}$ & MAP, mm & Altitude, $\mathrm{m}$ & $\begin{array}{l}\text { Study area size } \\
(\mathrm{km} \times \mathrm{km})\end{array}$ \\
\hline Finland & $62.6 ; 29.9$ & 2.1 & 700 & $80-200$ & $150 \times 150$ \\
Poland & $52.7 ; 23.9$ & 6.9 & 627 & $135-185$ & $30 \times 40$ \\
Germany & $51.1 ; 10.5$ & 6.8 & 775 & $500-600$ & $15 \times 10$ \\
Romania & $47.3 ; 26.0$ & 6.8 & 800 & $600-1000$ & $5 \times 5$ \\
Italy & $43.2 ; 11.2$ & 13.0 & 850 & $260-525$ & $50 \times 50$ \\
Spain & $40.7 ;-1.9$ & 10.2 & 499 & $960-1400$ & $50 \times 50$ \\
\hline
\end{tabular}

(Bauhus et al., 2000; Chen and Klinka, 2003; Brassard et al., 2011; Lei et al., 2012a). There are no comprehensive studies explaining the inconsistent responses of fine root biomass or productivity to tree species diversity. The varying above-ground biomass and productivity responses have been related to different climatic conditions and site productivity (Paquette and Messier, 2011; Jucker et al., 2014a, Jucker et al., 2016; Potter and Woodall, 2014; Ratcliffe et al., 2015; Toïgo et al., 2015; Wu et al., 2015), suggesting that responses are positive under cold or dry climatic conditions and at low site productivity. Thus, systematic studies covering a wide range of mature forest ecosystems and tree species and their combinations are still needed to understand below-ground productivity responses to tree species diversity, identity, stand characteristics and soil properties.

We conducted this study to assess the relationships between tree species diversity, conifer proportion, stand basal area and soil properties on tree and ground vegetation fine root biomass in the six major European forest types (boreal forest in Finland, temperate forests in Poland, Germany and Romania, thermophilous deciduous forests in Italy, and Mediterranean forests in Spain). For this we used the exploratory sites of the FunDivEUROPE project (Baeten et al., 2013), which allowed us to generalize the results over the major forest types in Europe and cover a range of natural species mixtures and monocultures in varying climatic and soil conditions. We tested the following hypotheses: (1) tree and ground vegetation fine root biomass in European forests increases by tree species diversity, (2) this response to tree species diversity is stronger under cold and dry environmental conditions than under more favourable conditions, (3) tree fine roots grow deeper in soil by increasing tree species diversity, and (4) tree fine root biomass increases by conifer proportion, stand basal area and soil C:N ratio more than by tree species diversity.

\section{Materials and methods}

\subsection{Experimental sites}

This study was carried out at the six FunDivEUROPE field sites (http://www.fundiveurope.eu/) established in the main European forest types for assessing the effect of tree species diversity (Table 1) on ecosystem functioning (Baeten et al., 2013). On each site 28-43 plots were established using predefined criteria on evenness, admixture, age distribution, tree density and site factors such as topography, soil type, previous land-use and management to minimize the effects of confounding factors on the results. Mature forest stands were growing on all plots of the sites ranging in species richness from one to five tree species depending on the local species pool (Table 2). The forest stands 
Table 2

The tree species growing at the six sites in monocultures and in mixtures. * indicates the species not presented in monocultures. In Finland the number of replicates for each species in monocultures is 3 and $0-2$ at the other sites.

\begin{tabular}{ll}
\hline Site & Species \\
\hline Finland & $\begin{array}{l}\text { Picea abies (L.) Karst., Pinus sylvestris L., Betula pendula Roth./B. } \\
\text { pubesecens } \text { Ehrh. }\end{array}$ \\
Poland & $\begin{array}{l}\text { Picea abies (L.) Karst., Pinus sylvestris L., Betula pendula Roth*., Quercus } \\
\text { robur L., Carpinus betulus L. }\end{array}$ \\
Germany & $\begin{array}{l}\text { Picea abies (L.) Karst., Quercus spp., Fagus sylvatica L., Acer } \\
\text { pseudoplatanus L.*, Fraxinus excelsior } \text { L. }\end{array}$ \\
Romania & $\begin{array}{l}\text { Picea abies (L.) Karst., Abies alba Mill., Fagus sylvatica L., Acer } \\
\text { pseudoplatanus L. } \\
\text { Italy }\end{array}$ \\
Quercus cerris L., Quercus petraea (Matt.) Liebl., Quercus ilex L., \\
Castanea sativa Mill., Ostrya carpinfolia Scop. \\
Pinus nigra Arnold, Pinus sylvestris L., Quecus ilex L., Quercus faginea \\
Lam.
\end{tabular}

were mostly uneven-aged, naturally regenerated except in Finland, where single species stands were planted and also one of the species in mixtures. The stand age on the plots was 39-49 years in Finland, 73-193 years in Poland, 65-100 years in Romania and 30-80 years in Italy. In Germany and Spain stand age was not determined. The plots comprised a canopy layer, and in addition a ground layer with herbaceous plants, shrubs and recruits. On the plots all trees with a breast height diameter $(\mathrm{DBH}) \geq 7.5 \mathrm{~cm}$ were recorded and $\mathrm{DBH}$ and height were measured (Jucker et al., 2014a).

Field sampling for fine root biomass was conducted one time by the same persons from May to October in 2012 on the 209 plots, sized $30 \mathrm{~m} \times 30 \mathrm{~m}$ (Table 3). Each plot was divided into nine $10 \mathrm{~m} \times 10 \mathrm{~m}$ subplots, and one soil sample was taken from each subplot. The organic layer on the top of the mineral soil was sampled using a wooden frame, sized $25 \mathrm{~cm} \times 25 \mathrm{~cm}$, and its depth was recorded (Table A1). After removal of the organic layer the mineral soil was sampled to depth of $20 \mathrm{~cm}$ depth using a cylindrical metal corer with an inner diameter of $3.6 \mathrm{~cm}$. The sampling was limited to depth of $20 \mathrm{~cm}$ due to the high stone content in the soil. In Spain the sampling was limited to $10 \mathrm{~cm}$ due to extremely rocky soil. Subsequently, the mineral soil cores were divided into $10 \mathrm{~cm}$ sections, and all respective soil layers from the nine subplots within one plot were pooled and sent for further analyses to Joensuu, Finland, where the samples were stored at $-18^{\circ} \mathrm{C}$ after arrival until further analyses. Concurrently with the root biomass sampling, the mineral soil volumetric stone content was estimated using the rod penetration method (Viro, 1952; Tamminen and Starr, 1994) (Table A1). Furthermore, fine roots of the different tree species, as well as a combined sample of ground vegetation species, were collected from four to five plots at each site (both monocultures and mixed species plots) for the near-infrared reflectance spectroscopy (NIRS) calibration analyses.

\subsection{Laboratory analyses}

All living fine roots (diameter $\leq 2 \mathrm{~mm}$ ) were separated by hand from the organic and mineral soil samples. The separation of living and dead roots was based on root branching patterns, periderm colour, surface structure, root elasticity and toughness (Persson, 1983). The roots were washed and divided into two categories: roots of trees and roots of ground vegetation. The sorting was done by experienced laboratory technicians using living tree and ground vegetation sample roots of the species identified and collected from the sites. The root samples were washed with water to remove adhering soil, dried at $40{ }^{\circ} \mathrm{C}$ until a constant weight was achieved and weighed for biomass assessment. Subsequently, the fine root biomass samples were ground (IKA A10; IKA, Staufen, Germany) for NIRS analyses. The soil from the cores was analysed separately for total $\mathrm{C}$ and total nitrogen (N) as described by Dawud et al. (2016, 2017).

The calibration samples for NIRS analyses were treated like the other root samples. Calibration mixtures were prepared for single species and all combinations of species for each site individually and with increasing additions of approximately $10 \%$ of the respective species. The roots of individual tree species, as well as the pooled fine roots of the ground vegetation, were used for the calibration mixtures. Depending on the number of tree species per site, 10-15-species combinations were used for the two-species mixtures (six for Finland where the species pool was small), 10 -species combinations for the threespecies mixtures (four for Finland), five-species combinations for the four-species mixtures and a one-species combination for the five-species mixtures. This resulted in 252 samples for the two-species mixtures, 261 samples for the three-species mixtures, 265 samples for the fourspecies mixtures and 153 samples for the five-species mixtures. Altogether, 1030 calibration mixtures and 636 fine root samples were used.

The NIRS spectra of the root samples, as well as the calibration mixtures, were analysed with a FTIR Spectrometer (Shimadzu IR Prestige-21, Kyoto, Japan), equipped with an integrating sphere (NIR IntegratIR, PIKE Technologies, WI, USA). Each spectrum was recorded as the average of 64 scans over the range between 3800 and $10,000 \mathrm{~cm}^{-1}$ (i.e. $1000-2600 \mathrm{~nm}$ ) with a resolution of $80 \mathrm{~mm}^{-1}$. Three spectra were taken from each sample and averaged before further statistical analyses.

\subsection{Calculation of fine root biomass, diversity indices and net diversity effects}

Fine root biomass was calculated as $\mathrm{g} \mathrm{m}^{-2}$. In mineral soil layers fine root biomass was corrected for stoniness by using the respective

Table 3

The dates of biomass sampling in 2012 and the number of study plots and basic stand characteristics at different tree species richness levels in the six sites.

\begin{tabular}{|c|c|c|c|c|c|c|c|c|c|c|}
\hline \multirow[t]{2}{*}{ Site } & \multirow{2}{*}{$\begin{array}{l}\text { Date (day/ } \\
\text { month) }\end{array}$} & \multicolumn{6}{|c|}{ Number of plots at different richness levels } & \multirow[t]{2}{*}{ Mean basal area, $\mathrm{m}^{2} \mathrm{ha}^{-1}( \pm \mathrm{SEM})$} & \multirow[t]{2}{*}{ Mean stand density, trees ha ${ }^{-1}( \pm$ SEM $)$} & \multirow{2}{*}{$\begin{array}{l}\text { Mean, min } \\
\text { and max of } \\
\text { conifer } \%\end{array}$} \\
\hline & & 1 & 2 & 3 & 4 & 5 & Total & & & \\
\hline Finland & $10 / 9-28 / 9$ & 11 & 14 & 3 & & & 28 & $20.9 \pm 0.8$ & $890 \pm 51$ & $73 ; 0 ; 100$ \\
\hline Poland & $14 / 5-25 / 5$ & 6 & 11 & 13 & 11 & 2 & 43 & $37.5 \pm 1.3$ & $499 \pm 39$ & $40 ; 0 ; 98$ \\
\hline Germany & $20 / 8-31 / 8$ & 6 & 14 & 14 & 4 & & 38 & $35.4 \pm 0.9$ & $533 \pm 51$ & $10 ; 0 ; 93$ \\
\hline Romania & $10 / 9-19 / 9$ & 8 & 10 & 8 & 2 & & 28 & $28.8 \pm 1.9$ & $535 \pm 31$ & $46 ; 0 ; 100$ \\
\hline Italy & $8 / 10-18 / 10$ & 9 & 10 & 9 & 7 & 1 & 36 & $26.6 \pm 1.3$ & $759 \pm 53$ & 0 \\
\hline Spain & $4 / 6-14 / 6$ & 11 & 18 & 4 & 3 & & 36 & $22.1 \pm 2.1$ & $910 \pm 95$ & $54 ; 0 ; 100$ \\
\hline Total & & 51 & 77 & 51 & 27 & 2 & 209 & & & \\
\hline
\end{tabular}


plot-wise volumetric stone content (Table A1) (Viro, 1952; Tamminen and Starr, 1994). The weighted mean depth of fine root biomass was calculated for the organic $+0-20 \mathrm{~cm}$ mineral soil layer by weighting the root biomass in each layer by the depth of the layer.

The tree species diversity was characterized by using the Shannon diversity index (Shannon, 1948), accounting for tree species richness and evenness (Jost, 2006) based on the proportional basal area contributions of each tree species. The Shannon diversity index was further converted into number of tree species (true Shannon diversity) to facilitate the comparisons of diversity values (Jost, 2006).

The species diversity effects on fine root biomass were assessed by using the true Shannon diversity index as an explaining variable. In addition, the net diversity effect (NDE) was calculated as the proportional deviation between the fine root biomass in the mixtures and the biomass expected from the corresponding monocultures, weighted by the basal area proportion of each tree species in the mixture (SchererLorenzen et al., 2007). Net diversity effects were calculated separately for tree and ground vegetation fine root biomasses and for the fine root biomasses of pure broadleaf and pure conifer stands. The NDE values $=0$ were considered as additive, NDE values $>0$ as positive and those $<0$ as negative. The NDE values could not be calculated in cases where tree species were not present in monocultures, which occurred in Germany (Acer) and in Poland (Betula).

\subsection{Statistical analyses}

The data were analysed with linear regression models by using the statistical package $\mathrm{R}$ version 3.3.1 (R Core Team, 2016). The response variables were the fine root biomasses of trees, ground vegetation, trees and ground vegetation combined in different soil layers and their combinations and the weighted mean root depth of trees and ground vegetation. Responses of different tree species could not be assessed at tree species level as the tree species composition varied between sites. Thus the responses were assessed separately for two functional groups, which were formed by aggregating stands with only broadleaf trees and only conifer trees, respectively. The continuous explanatory variables were true Shannon diversity, conifer proportion (\% of stand basal area), stand basal area, soil carbon (C) stock and C:N ratio. Collinearity between explanatory variables was identified using variance inflation factors (vif) using the 'car' package in R. The variable with the highest variance inflation factors (generally VIF $>15$ ), in this case N stock, was removed, rendering the variance inflation factors of the other variables under the generally still as satisfactory regarded threshold value of VIF $<5$, and in few cases VIF $<10$ (Kock and Lynn, 2012).

Site was used as a categorical explanatory variable with six levels, Finland, Poland, Germany, Romania, Italy and Spain. The data were log-transformed before analyses when needed to normalize the distribution of residuals. Non-significant interactions were removed from the ANOVA (Crawley, 2012). The relative importance of the explanatory variables was assessed using the relaimpo package in $\mathrm{R}$ and the lmg metric (Grömping, 2006) The differences between sites in the weighted mean depth of fine root biomass was analysed with linear mixed models using SPSS Statistics Version 22.0 (IBM Corp., NY, USA). Post-hoc comparisons were made using Bonferroni's multiple comparison tests. One-sample $t$-tests were used to assess whether the NDE values deviated from zero. Results were regarded to be significant at $p$ values $<0.05$.

Data analyses of the near-infrared spectra were performed by multivariate partial least squares (PLS) regression using The Unscrambler X (version 10.1, Camo Software AS, Oslo, Norway). In addition to no treatment, mathematical pre-treatments during data analyses comprised $1 / \mathrm{x}$ weighting of the original $\mathrm{x}$-data, the first and second derivatives of Savitzky-Golay smoothing, mean and peak normalisation, and Multiplicative Scatter Correction (MSC) (Esbensen, 2001; Vávřová et al., 2008; Rinnan et al., 2009). We used spectra between $1450 \mathrm{~nm}$ and $2500 \mathrm{~nm}$ wavelengths as the other parts contained background noise. Both PLS 1 and PLS 2 models were tested and since the PLS 1 models, pre-treated with MSC, performed better in terms of RMSE and $\mathrm{R}^{2}$, they were used for estimating the fine root species proportions within the samples. The models were constructed for each tree species and for each site individually (Table A2). The analyses included multivariate calibration and validation with one third of the samples (Esbensen, 2001), while the other two thirds were used to construct the models. All analysed samples showed the presence of the respective target tree species (Table 2), and thus we conclude that our sampling was representative for the whole respective plot.

\section{Results}

3.1. Tree species diversity effects on tree, ground vegetation and total fine root biomass

There was no general effect of tree species diversity on tree, ground vegetation or total fine root biomass (Fig. 1, Fig. A1, Tables A3-A5). The net diversity effects were mostly insignificant, except the weak negative effects on the tree fine root biomass in the organic layer and the ground vegetation fine root biomass in the $0-10 \mathrm{~cm}$ mineral soil layer (Fig. 2). However there was a significant interaction between conifer proportion and tree species diversity for the tree and ground vegetation fine root biomass in the organic $+0-10 \mathrm{~cm}$ mineral soil layer and in the $0-10 \mathrm{~cm}$ mineral soil layer, respectively. Due to these significant interactions the analyses were carried out separately for the pure broadleaf and pure conifer stands, which revealed a positive relationship between tree species diversity and the tree fine root biomass in the organic $+0-10 \mathrm{~cm}$ soil layer for the broadleaf stands, but not for the conifer stands (Fig. 3, Table A6). Species diversity explained $7 \%$ of the variation in tree fine root biomass in the broadleaf stands. The tree fine root biomass in the organic $+0-10 \mathrm{~cm}$ layer in the most diverse broadleaf stands was on average twice as high as that of the broadleaf monocultures. The net diversity effects for tree fine root biomass were negative (NDE $<0$ ) in the organic layer in the four-species broadleaf mixtures and positive in the $0-10 \mathrm{~cm}$ mineral soil layer for the three-species broadleaf mixtures (Fig. 4). The separate analyses for ground vegetation fine root biomass in pure broadleaf and pure conifer stands did not show any significant diversity effects.

\subsection{Relationships between tree stand and soil factors and fine root biomass}

The tree fine root biomass in the organic $+0-10 \mathrm{~cm}$ soil layer was highest in Italy, followed by Germany, Poland, Finland, Romania and Spain (Table 4). The ground vegetation fine root biomass (organic + $0-10 \mathrm{~cm}$ layer) was highest in Finland and Spain, and very low $\left(<10 \mathrm{~g} \mathrm{~m}^{-2}\right)$ in the other sites. The ground vegetation fine root biomass was smaller than that of trees in all sites and in all soil layers. The total fine root biomass in the organic $+0-10 \mathrm{~cm}$ layer was highest in Finland, followed by Italy, Poland, Germany, Spain and Romania, and in the organic $+0-20 \mathrm{~cm}$ layer the total root biomass was highest in Italy, followed by Finland, Poland, Germany and Romania.

In the organic layer the tree and total fine root biomass was positively related to conifer proportion and soil C stock and negatively to soil C:N ratio, and the ground vegetation fine root biomass positively to 

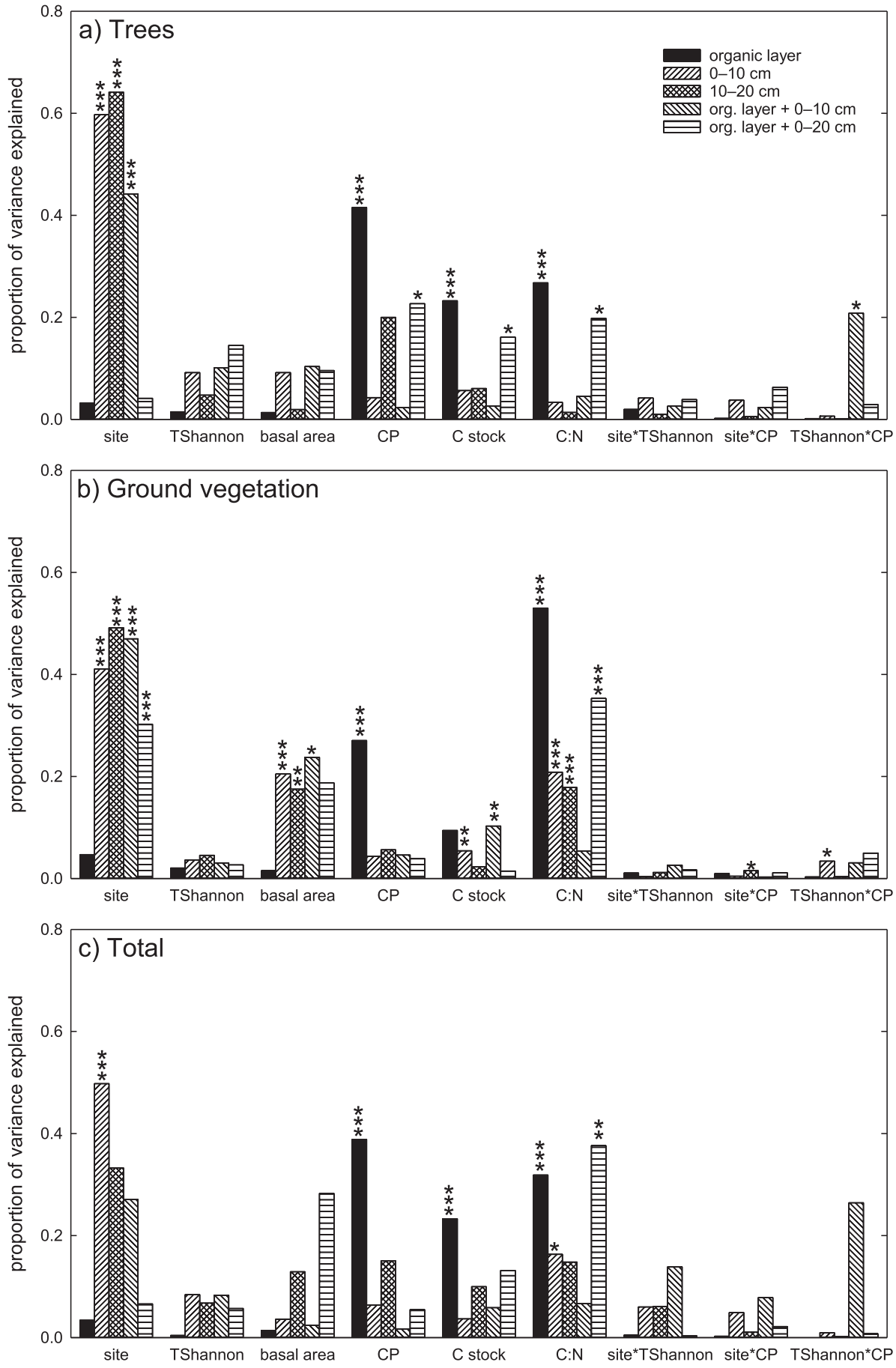

Fig. 1. Relative importance of site, true Shannon diversity, stand basal area, conifer proportion (CP), C stock, C:N ratio, interactions between, site and true Shannon diversity, site and conifer proportion and true Shannon diversity and conifer proportion in explaining (a) tree, (b) ground vegetation and (c) total fine root biomass in the organic, $0-10 \mathrm{~cm}$ and $10-20 \mathrm{~cm}$ mineral soil layers and the combined organic + mineral soil layers. The proportion of explained variance of the models $\left(\mathrm{R}^{2}\right)$ for these layers were 53 , $48,24,39,41 \%$, respectively for tree fine root biomass 34 , $54,71,39,42 \%$, respectively for ground vegetation fine root biomass and $53,51,20,40,44 \%$, respectively for total fine root biomass. Significant effects (Tables A1-3) are indicated by asterisks $\left(* \mathrm{p}<0.05,{ }^{*} \mathrm{p}<0.05,{ }^{* * *} \mathrm{p}<0.001\right)$. conifer proportion and negatively to C:N ratio (Fig. 5). These variables explained $12-34 \%$ of the variation of the tree, $2-14 \%$ of the ground vegetation and $12-21 \%$ of the total fine root biomass in the organic layer. The highest proportion of the variation in tree and ground vegetation fine root biomass in the mineral soil layers and in the organic $+0-10 \mathrm{~cm}$ mineral soil layers was explained by site, i.e. $19-34 \%$ and $11 \%$, respectively. For the total fine root biomass site explained $6 \%$ of the variation in the $0-10 \mathrm{~cm}$ mineral soil layer. The differences in fine root biomass between sites were not correlated with mean annual temperature, mean annual precipitation, stand basal area or the studied soil characteristics (Figs. A2 and A3).

Conifer proportion, $\mathrm{C}$ stock and $\mathrm{C}: \mathrm{N}$ ratio explained significant proportions of the variation in tree fine root biomasses in the organic + $0-20 \mathrm{~cm}$ mineral soil layer $(2.5,1.7$ and $2.1 \%$, respectively). Tree fine 

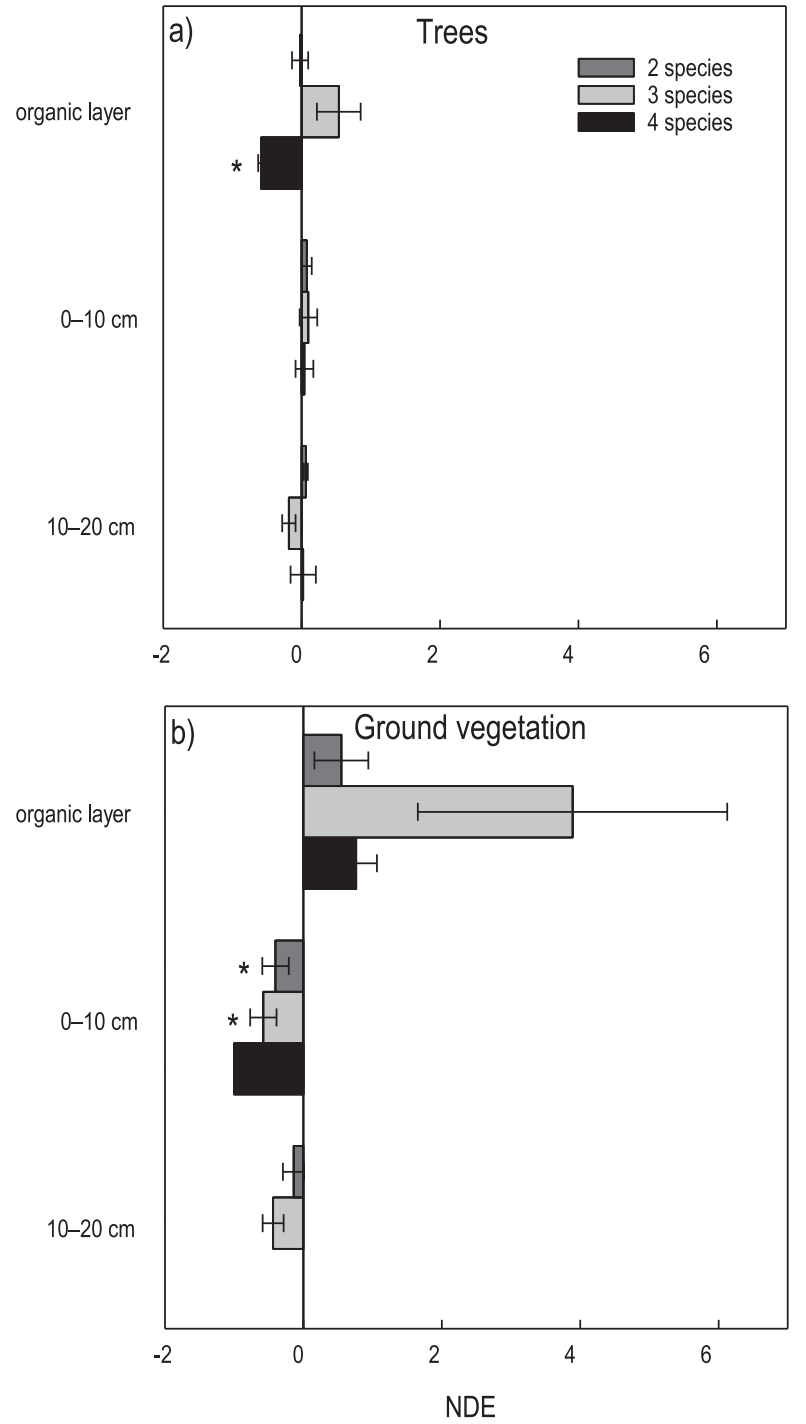

Fig. 2. Net diversity effects for (a) tree and (b) ground vegetation fine root biomass in the organic, $0-10 \mathrm{~cm}$ and $10-20 \mathrm{~cm}$ mineral soil layers and in the combined organic $+\mathrm{mi}-$ neral soil layers in the 2-4 tree species stands compared to monocultures. Error bars are mean \pm SEM. Significant effects are indicated by asterisk (*p $<0.05)$.

root biomass increased with conifer proportion and $\mathrm{C}$ stock in the same way as in the organic layer (Fig. 5). Oppositely to the trends in the organic layer tree fine root biomass increased with $\mathrm{C}: \mathrm{N}$ ratio in the organic $+0-20 \mathrm{~cm}$ mineral soil layer (Fig. 5). For the ground vegetation fine root biomass conifer proportion had a significant interaction with site in the $10-20 \mathrm{~cm}$ soil layer, because the ground vegetation fine root biomass was negatively related to conifer proportion in that layer in Finland (Fig. A4). Besides site, basal area, soil C stock and C:N ratio also explained significant proportions of the variation in the ground vegetation fine root biomass in the $0-10 \mathrm{~cm}$ mineral soil layer, and basal area and C:N ratio in the $10-20 \mathrm{~cm}$ mineral soil layer. In addition basal area and C stock explained significant proportions of the variation in ground vegetation fine root biomass in the organic $+0-10 \mathrm{~cm} \mathrm{mi}-$ neral soil layer and C:N ratio the highest proportion of all variation of ground vegetation fine root biomass in the organic $+0-20 \mathrm{~cm}$ mineral soil layer. The relationship between basal area and soil $\mathrm{C}$ stock and the

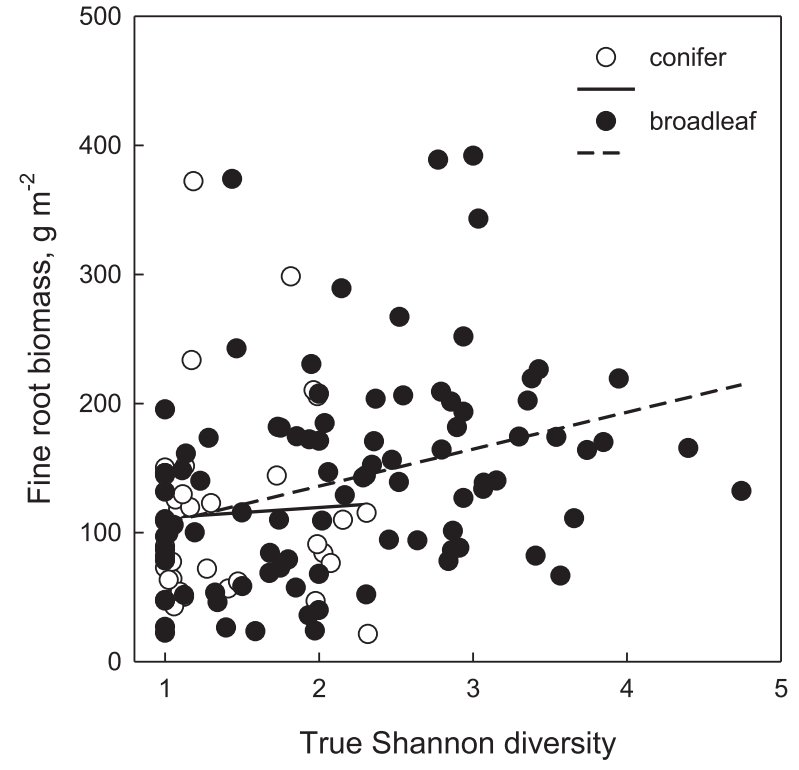

Fig. 3. Relationship between true Shannon diversity and fine root biomass in the organic $+0-10 \mathrm{~cm}$ mineral soil layer in conifer and broadleaf stands. Linear regression lines are indicated, equation for broadleaf tree species: $y=103.51+7.95 x, R^{2}=0.109$, $\mathrm{p}=0.001$ and for conifers $\mathrm{y}=78.61+28.65 \mathrm{x}, \mathrm{R}^{2}=0.002, \mathrm{p}=0.781$.

ground vegetation fine root biomass was negative whereas that of C:N ratio and the ground vegetation fine root biomass was positive. There was a clear positive trend for higher tree fine root biomass with higher basal area, but it was not significant.

\subsection{Factors affecting vertical distribution of fine root biomass in the studied soil layers}

The weighted mean vertical depth of the tree or ground vegetation fine root biomass was not affected by tree species diversity in the organic $+0-20 \mathrm{~cm}$ mineral soil layer (Table A8). However, the weighted mean depth of fine root biomass differed between sites, and tree root distribution was more superficial in Finland than in other sites (Table 5). The weighted mean depth of ground vegetation roots did not differ between Finland and Poland, but was deeper than in the other sites. Conifer proportion, $\mathrm{C}$ stock and $\mathrm{C}: \mathrm{N}$ ratio were negatively related to the weighted mean depth of tree fine root biomass, but not with that of ground vegetation (Table A8, Fig. A5). The sampling depth in Spain was only 10 $\mathrm{cm}$ in mineral soil, however, the weighted mean depth of tree fine root biomass did not differ $(p>0.05)$ between Spain and Finland and that of ground vegetation did not differ between Spain, Finland and Poland. At all sites the ground vegetation fine root biomass was more superficially distributed in the soil than the tree fine root biomass.

\section{Discussion}

\subsection{Diversity effects on fine root biomass}

Our results did not confirm the first hypothesis of differences in tree and ground vegetation fine root biomass in tree species-diverse forests compared to monocultures across major European forest types and tree species combinations. Therefore our findings also do not conform to those of a previous study in boreal North America where fine root biomass responded positively to tree species diversity in mature forests 

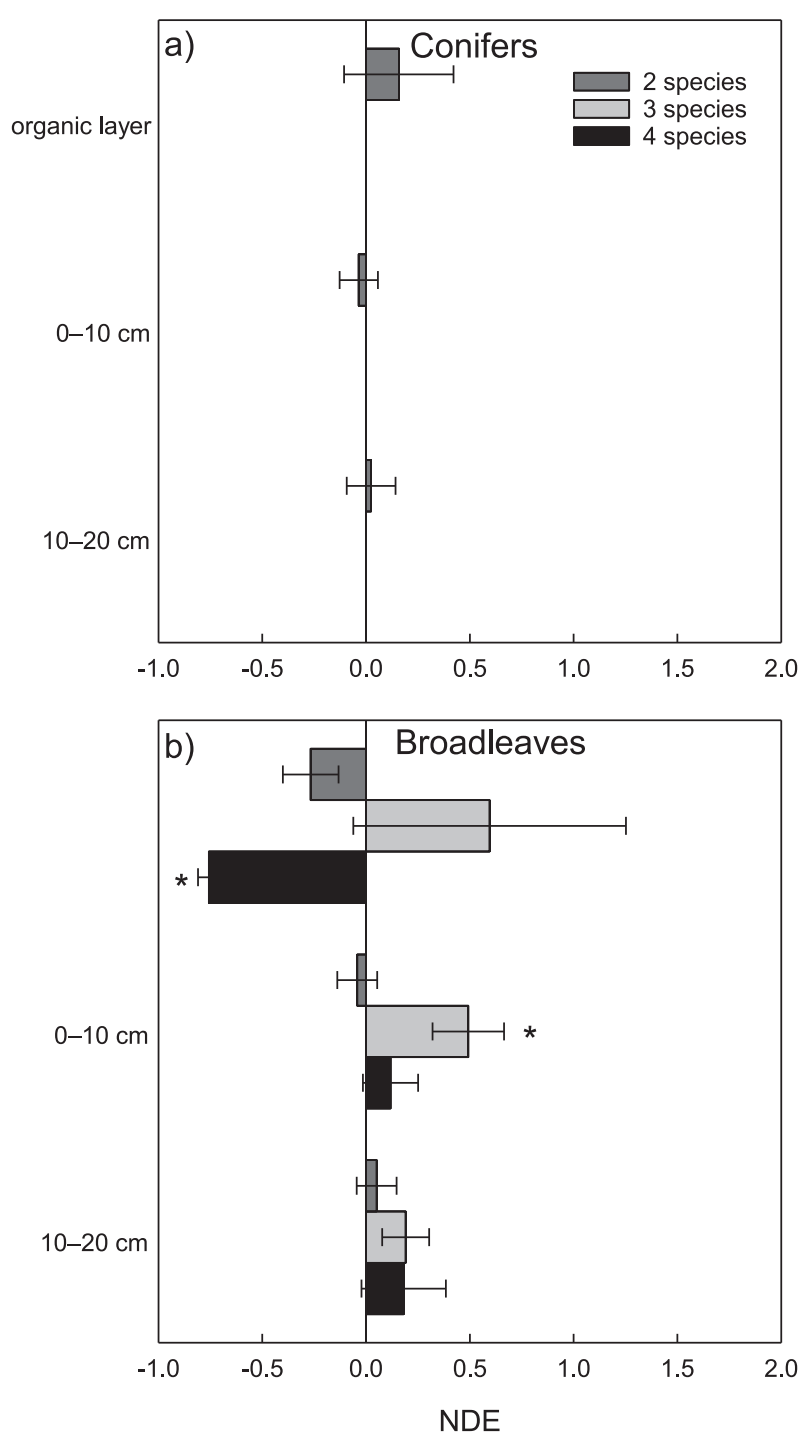

Fig. 4. Net diversity effects for fine root biomass in the organic, $0-10 \mathrm{~cm}$ and $10-20 \mathrm{~cm}$ mineral soil layers in the 2-4 tree species (a) conifer and (b) broadleaf stands compared to monocultures. Error bars are mean \pm SEM. Significant effects are indicated by asterisks $(* \mathrm{p}<0.05)$

consisting of mixtures of conifers and broadleaf species (Brassard et al., 2011), but agree more with studies conducted in young temperate broadleaf-conifer plantations where tree or ground vegetation fine root biomass did not differ between monocultures and 2-4 species mixtures (Lei et al., 2012b, Domisch et al., 2015). Our forest stands were middleaged forests, and earlier the positive diversity effect on both on aboveground (Zhang et al., 2012) and fine root productivity has been proposed to be more distinct in middle-aged forests than in young forests (Ma and Chen, 2017). The weak response might indicate that the response of fine root biomass to species diversity differs from the positive response reported for above-ground biomass on the same sites (Jucker et al., 2016). Our fine root sampling was carried out only once and we were unable to do it at the same time of the growing season at all sites, which could mask some of the diversity effects. Earlier studies demonstrated that positive fine root biomass responses to species mixing can vary between seasons (Brassard et al., 2013, Ma and Chen, 2017). They may also be less pronounced during dry periods as observed in above-ground parts of trees (Grossiord et al., 2014; Jucker et al., 2014b).

In contrast to a general positive effect of species diversity on fine root biomass, our results suggest that fine root biomass is higher in species-diverse broadleaf stands compared to broadleaf monocultures. In broadleaf stands tree species diversity was responsible for up to $7 \%$ of the variation in tree fine root biomass in the organic $+0-10 \mathrm{~cm}$ mineral soil layer. We did not find any diversity response in conifer stands. The limited number of tree species and functional traits in the studied conifer stands (only 2 species) compared to a wider species diversity gradient in the broadleaf stands ( 4 species) could be a reason for the lack of response for conifers. The small number of conifer tree species may have decreased our probability of having species combinations featuring below-ground functional traits with over-yielding capacity. The importance of selecting species combinations with contrasting functional traits has been demonstrated to drive significant positive diversity effects in tree communities (Jacob et al., 2010; Zhang et al., 2012; Lübbe et al., 2015; Tobner et al., 2016).

The NIRS assessments gave rather good results when constructing the calibration models. Similarly, the regression analyses for estimating the species-specific proportions in the root samples generally showed acceptable results. The models were somewhat better for broadleaf tree species and ground vegetation than for conifers, which were also observed by Lei and Bauhus (2010) and Domisch et al. (2015). However, the predictions were rather uncertain (high RMSEP values) for some tree species, particularly for Pinus sylvestris, $P$. nigra, Carpinus betulus and Quercus cerris. This could have affected the results presented for the functional groups, especially those of conifers by masking some of the differences due to the high variation.

Our second hypothesis, regarding a positive response of fine root biomass to tree species diversity under harsh environmental conditions was also rejected. There was a consistent lack of tree species diversity response among the different forest types, representing a wide range of climatic conditions from cool boreal forests in Finland to thermophilous forests in Italy and from dry Mediterranean forests in Spain to humid forests in Finland. Neither were the diversity effects related to soil C:N ratio. A study conducted on the same sites concluded that the aboveground tree productivity responded more positively to tree species diversity under more harsh environmental conditions in Finland and Spain, compared to the other sites with a more favourable climate for growth (Jucker et al., 2016). We found no clear evidence that this effect is mirrored in below-ground root biomass.

The tree fine root biomass had the most shallow distribution in Finland and Spain, which could be attributed to the harsh environmental conditions i.e. cold in Finland and dry in Spain. Tree fine root biomass was largest in the $0-10 \mathrm{~cm}$ mineral soil layer in all sites, except in Finland, where the tree root biomasses were almost equal in the organic layer and in the $0-10 \mathrm{~cm}$ mineral soil. The Finnish site had a thick, organic layer with higher $\mathrm{N}$ stock than the deeper mineral soil layers compared to the other sites (Dawud et al., 2017). As the poor supply of N limits growth in boreal forests (Tamm, 1991), the higher amount of $\mathrm{N}$ and higher temperatures in topsoil layers, which enhance mobilisation and better supply of $\mathrm{N}$ could favour the rather shallow allocation of fine roots. Although the weighted mean root depth was not affected by the tree species diversity, some evidence of diversity mediated changes in the vertical rooting patterns of the broadleaf trees were found, partly supporting our third hypothesis that tree roots grow deeper in soil by increasing tree species diversity, and the results of Sun et al. (2017), who found a significant positive relationship between tree species richness and the evenness on the vertical distribution of tree fine-root standing biomass. Negative diversity effects on tree fine root biomass were observed in the organic layer in the four species mixtures, 
Table 4

Tree, ground vegetation and total fine root biomass $\left(\mathrm{g} \mathrm{m}^{-2}\right)$ in the different soil layers and their combinations in the six sites.

\begin{tabular}{|c|c|c|c|c|c|c|c|c|}
\hline \multirow[t]{2}{*}{ Site } & \multirow[t]{2}{*}{ Soil layer } & \multicolumn{2}{|l|}{ Trees } & \multicolumn{2}{|c|}{ Ground vegetation } & \multicolumn{2}{|l|}{ Total } & \multirow[t]{2}{*}{$\mathrm{n}$} \\
\hline & & Mean & $\pm \mathrm{SEM}$ & Mean & \pm SEM & Mean & \pm SEM & \\
\hline \multirow[t]{5}{*}{ Finland } & Organic layer & 63.2 & 11.3 & 20.8 & 3.0 & 84.0 & 10.9 & 27 \\
\hline & $0-10 \mathrm{~cm}$ & 80.5 & 7.5 & 32.7 & 4.8 & 113.2 & 8.7 & 28 \\
\hline & $10-20 \mathrm{~cm}$ & 41.9 & 3.6 & 12.1 & 1.6 & 54.0 & 4.1 & 28 \\
\hline & Organic $+0-10 \mathrm{~cm}$ & 141.4 & 15.8 & 52.8 & 6.9 & 194.2 & 16.2 & 28 \\
\hline & Organic $+0-20 \mathrm{~cm}$ & 183.4 & 16.6 & 64.9 & 8.1 & 248.2 & 17.8 & 28 \\
\hline \multirow[t]{5}{*}{ Poland } & Organic layer & 9.6 & 2.4 & 4.6 & 0.6 & 14.24 & 2.8 & 43 \\
\hline & $0-10 \mathrm{~cm}$ & 145.7 & 7.0 & 5.1 & 1.0 & 150.8 & 7.3 & 43 \\
\hline & $10-20 \mathrm{~cm}$ & 67.4 & 3.2 & 0.6 & 0.2 & 68.1 & 3.2 & 43 \\
\hline & Organic $+0-10 \mathrm{~cm}$ & 155.3 & 7.2 & 9.7 & 1.1 & 165.0 & 16.2 & 43 \\
\hline & Organic $+0-20 \mathrm{~cm}$ & 222.8 & 8.9 & 10.3 & 1.2 & 233.1 & 9.30 & 43 \\
\hline \multirow[t]{5}{*}{ Germany } & Organic layer & 14.6 & 10.1 & 0.7 & 0.3 & 15.3 & 10.3 & 38 \\
\hline & $0-10 \mathrm{~cm}$ & 142.0 & 10.8 & 2.6 & 1.4 & 144.6 & 10.9 & 38 \\
\hline & $10-20 \mathrm{~cm}$ & 58.3 & 5.1 & 0 & 0 & 58.3 & 5.1 & 37 \\
\hline & Organic $+0-10 \mathrm{~cm}$ & 156.5 & 13.8 & 3.3 & 1.4 & 159.8 & 13.9 & 38 \\
\hline & Organic $+0-20 \mathrm{~cm}$ & 213.3 & 16.5 & 3.3 & 1.4 & 216.6 & 16.6 & 38 \\
\hline \multirow[t]{5}{*}{ Romania } & Organic layer & 22.0 & 3.8 & 3.4 & 0.7 & 25.4 & 4.5 & 28 \\
\hline & $0-10 \mathrm{~cm}$ & 93.6 & 10.5 & 1.1 & 0.8 & 94.7 & 10.3 & 28 \\
\hline & $10-20 \mathrm{~cm}$ & 47.7 & 4.3 & 0 & 0 & 47.7 & 4.3 & 26 \\
\hline & Organic $+0-10 \mathrm{~cm}$ & 115.6 & 12.2 & 4.5 & 1.0 & 120.1 & 12.0 & 28 \\
\hline & Organic $+0-20 \mathrm{~cm}$ & 159.9 & 15.4 & 4.5 & 1.0 & 164.4 & 15.1 & 28 \\
\hline \multirow[t]{5}{*}{ Italy } & Organic layer & 2.8 & 0.8 & 0.0 & 0.0 & 2.8 & 0.8 & 36 \\
\hline & $0-10 \mathrm{~cm}$ & 184.6 & 12.7 & 0 & 0 & 184.6 & 12.7 & 36 \\
\hline & $10-20 \mathrm{~cm}$ & 96.6 & 6.5 & 0 & 0 & 96.6 & 6.5 & 33 \\
\hline & Organic $+0-10 \mathrm{~cm}$ & 187.4 & 12.7 & 0.0 & 1.1 & 187.4 & 12.7 & 36 \\
\hline & Organic $+0-20 \mathrm{~cm}$ & 276.0 & 17.8 & 0.0 & 0.0 & 276.0 & 17.8 & 36 \\
\hline \multirow[t]{3}{*}{ Spain } & Organic layer & 6.9 & 3.4 & 1.5 & 0.4 & 8.3 & 3.5 & 36 \\
\hline & $0-10 \mathrm{~cm}$ & 97.7 & 9.3 & 19.4 & 3.8 & 117.1 & 11.8 & 36 \\
\hline & Organic $+0-10 \mathrm{~cm}$ & 104.6 & 10.1 & 20.9 & 3.9 & 125.5 & 12.5 & 36 \\
\hline
\end{tabular}

as well as on ground vegetation fine root biomass in the $0-10 \mathrm{~cm} \mathrm{mi-}$ neral soil layer in the three species mixtures. In contrast positive diversity effects were observed on broadleaf tree fine root biomass in the $0-10 \mathrm{~cm}$ mineral soil layer in the three species mixtures. These results could indicate increased competition between trees and ground vegetation in top mineral soil layers and also niche differentiation, inducing tree roots to exploit deeper soil layers in tree-species rich forests compared to monocultures and therefore gaining access to larger water and nutrient resources (Rothe and Binkley, 2001; Zapater et al., 2011). An increase in tree species diversity could also have caused changes in the species composition of the ground vegetation, favouring more shallow rooted species in the diverse forests or an allocation of relatively more biomass to the shoots on the expense of roots to increase competitiveness for light (Zhang et al., 2014). However no obvious difference in understorey vegetation composition was found among the tree species richness levels in the studied sites (Ampoorter et al., 2016). Our sampling depth was shallow (10 or $20 \mathrm{~cm}$ layers in mineral soil) caused by high stoniness at most of the sites, which could prevent us from discovering any stronger evidence for niche differentiation. However, significant signs of this were found in another study of the plots in Poland, where more fine root biomass and higher $\mathrm{C}$ stocks were found in the $30-40 \mathrm{~cm}$ mineral soil layer under mixed forests compared to monocultures (Dawud et al., 2016).

In this study we assessed only the responses of fine root biomass to species diversity. Other root related traits - such as nutrient uptake capacity (Göransson et al., 2008), root diameter classes, different rootorders or morphological traits (fine root length, root surface area, specific root length, the number of root tips) - could have shown responses to species diversity as well, because they were reported to explain the resource exploitation of trees better than root biomass (e.g. Ostonen et al., 2007; McCormack et al., 2015). Bolte and Villanueva (2006) suggested that root morphological parameters respond more clearly to stand structure than root biomass, but this was not supported by other studies assessing these relationships at ecosystem level in temperate or boreal forests (Meinen et al., 2009b; Lei et al., 2012a; Domisch et al., 2015).

\subsection{Other factors affecting fine root biomass}

The abundance of conifers increased tree and ground vegetation fine root biomass, especially in the organic layer. That was related to the increase in the thickness of the organic layer with conifer proportion (data not shown), as also suggested by the higher $\mathrm{C}$ and $\mathrm{N}$ stocks in the organic layer compared to the mineral soil, providing space for roots to exploit and take up nutrients (Dawud et al., 2017). In contrast, the conifer fine root biomass could also contribute to the organic layer $\mathrm{C}$ stocks by its input of slowly decomposing root litter (Augusto et al., 2015). Since the conifer proportion explained a significant proportion of the variation in tree and ground vegetation fine root biomass in the organic layer and in the organic $+0-20 \mathrm{~cm}$ mineral soil layers, it gave 

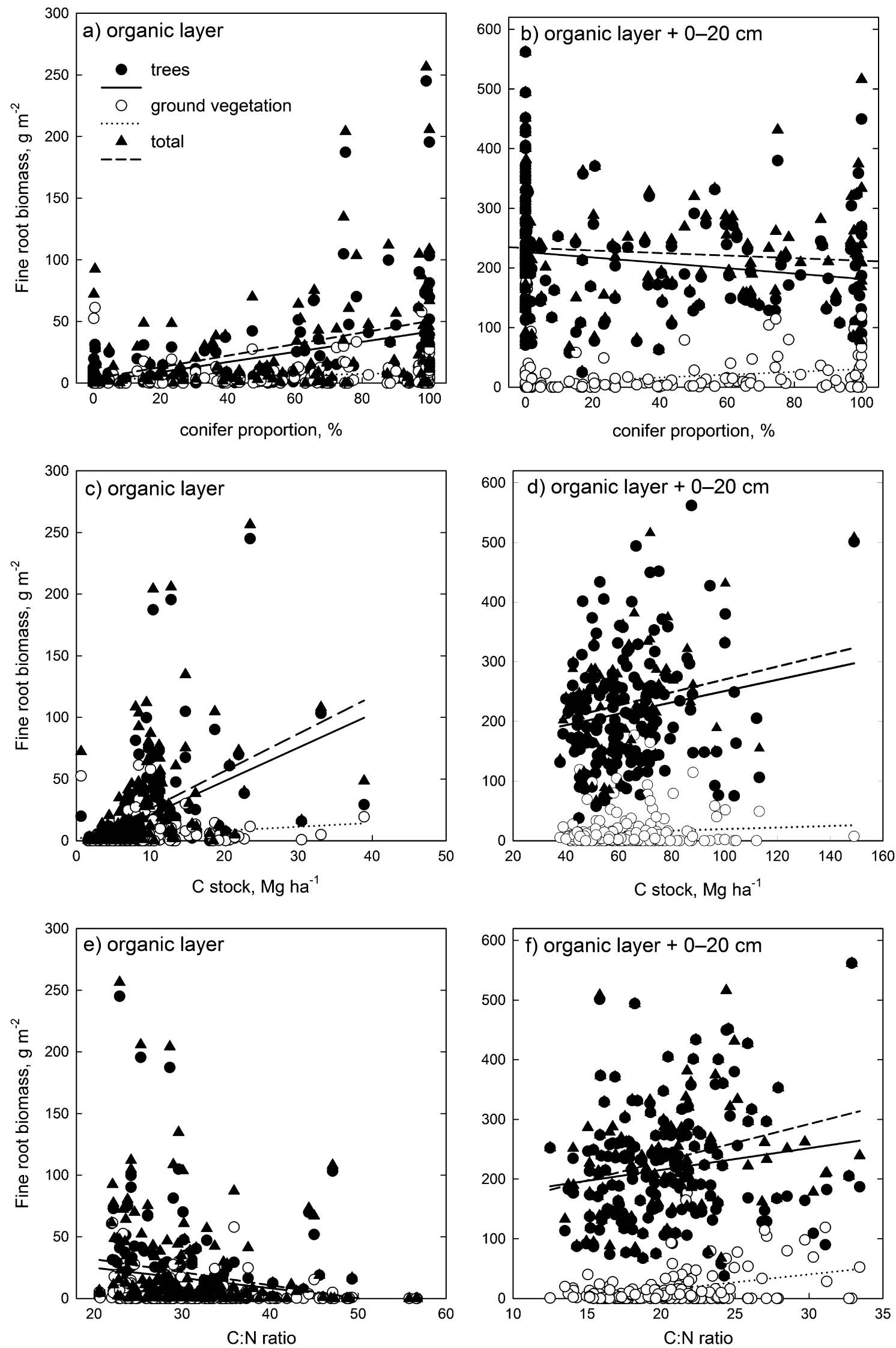

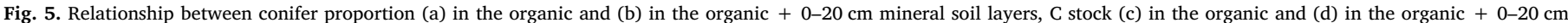

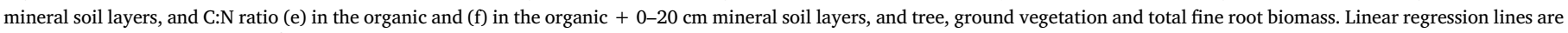
indicated. The equations with $\mathrm{R}^{2}$ and $\mathrm{p}$-values are presented in Table A7. 
Table 5

Weighted mean ( \pm SEM) depth of root biomass $(\mathrm{cm})$ of the trees and ground vegetation in the organic $+0-20 \mathrm{~cm}$ mineral soil layers in the six sites. Different upper case letters indicate statistically significant differences between sites and the lower case letters between trees and ground vegetation. The values in brackets are calculated for the organic $+0-10 \mathrm{~cm}$ mineral soil layer in Spain.

\begin{tabular}{lll}
\hline Site & Trees & Ground vegetation \\
\hline Finland & $6.78 \pm 0.26^{\mathrm{Aa}}$ & $5.81 \pm 0.24^{\mathrm{Ab}}$ \\
Poland & $9.74 \pm 0.89^{\mathrm{Ba}}$ & $4.17 \pm 2.55^{\mathrm{Ab}}$ \\
Germany & $8.80 \pm 0.23^{\mathrm{Ba}}$ & $0.93 \pm 0.31^{\mathrm{Bb}}$ \\
Romania & $9.00 \pm 0.34^{\mathrm{Ba}}$ & $1.23 \pm 0.21^{\mathrm{Cb}}$ \\
Italy & $9.28 \pm 0.21^{\mathrm{Ba}}$ & $0.01 \pm 0.01 \mathrm{D}^{\mathrm{b}}$ \\
Spain & $(5.91 \pm 0.22)$ & $(5.13 \pm 0.30)$ \\
\hline
\end{tabular}

support to our fourth hypothesis.

Site was the main factor explaining variation in the fine root biomass of trees and ground vegetation in the mineral soil layers and in the organic $+0-10 \mathrm{~cm}$ mineral soil layer. The sites of this study represent some major European forest types located along the climatic gradient from the boreal to temperate and Mediterranean forests. However, the differences in fine root biomass were not related to the climatic gradient in mean annual temperature nor mean annual precipitation as they did not either in the monocultures of European tree species in a wide climatic gradient (Finér et al., 2007). It remained unclear what caused the differences in fine root biomass between the studied European forests sites because the differences were not related to the stand basal area or to soil factors, which have explained between site variation for some European tree species in earlier studies (Finér et al., 2007; Helmisaari et al., 2007; Lehtonen et al., 2016). Generally our fine root biomass estimates were at the lower end of the range earlier reported for boreal and temperate forests (Finér et al., 2007, Finér et al., 2011), which is most likely due to our limited sampling depth caused by high stoniness. The average root sampling depths in the dataset of 84 sites in boreal and 221 sites in temperate forests reviewed by Finér et al. (2011) were $34 \mathrm{~cm}$ in boreal and $47 \mathrm{~cm}$ in temperate forests, covering $86 \%$ of the total fine root biomass in boreal and 68-85\% in the temperate forests calculated with the general equations presented by Jackson et al. (1996). According to the same equations our sampling depths covered $69 \%$ of the total fine root biomass in Finland, 22-29\% in Spain, 62-78\% in Poland and $38-50 \%$ at the other sites. Our sampling most probably covered higher proportions of fine root biomass because at our sites the subsoil had a high stone content, which was not taken into account in the general equations by Jackson et al. (1996).

There was a clear positive trend for more tree fine root biomass with higher basal area, but it was not significant. Oppositely stand basal area had a significant negative effect on the ground vegetation fine root biomass. A review study by Finér et al. (2011) covering a wide geographic area concluded that tree fine root biomass clearly increased with stand basal area. However, the variation in stand basal area in the reviewed stands was larger than in this study where only middle-aged forest stands were included, which could explain the weaker relationship. The negative response of the ground vegetation fine root biomass to stand basal area could be related to the associated increase in competition between ground vegetation and tree roots and to shading by the tree canopy. The significant positive relationships between soil $\mathrm{C}$ stock and the tree and total fine root biomass in the organic layer supported our fourth hypothesis and could indicate that tree roots contribute significantly to soil C stocks as demonstrated by Clemmensen et al. (2013). The significant positive relationship between tree fine root biomass in the organic $+0-20 \mathrm{~cm}$ mineral soil layer and soil C:N ratio also supported our fourth hypothesis, whereas the negative relationship in the organic layer could suggest that fine root biomass is related to the mineralization of $\mathrm{N}$ from soil organic matter.

\section{Conclusions}

The results of this study indicate that fine root biomass does not consistently increase in response to tree species diversity in the major European forest types, and other site factors can explain more of the variation in fine root biomass than tree species diversity. However, they suggest that the diversity responses depend on the tree species functional group and can be observed when species with various functional traits are combined, which is more often the case in European broadleaf forests than in species-poor conifer forests. There seems to be some evidence that in the species-rich broadleaf forests the access to soil resources might be facilitated by the allocation of more fine roots to the mineral soil than in the monocultures. More research covering the annual variation in fine root biomass and deeper soil layers is needed before growing species-rich forest can be recommended for increasing below-ground biomass and carbon pools.

\section{Data accessibility}

The data are stored at the FunDivEurope BEF data portalhttp:// fundiv.befdata.biow.uni-leipzig.de/. The website is publicly available.

\section{Acknowledgements}

We would like to thank the Hainich National Park administration in Germany for support in establishing the study sites and for logistical help during fieldwork at the German site. We are also grateful to Ms Sigrid Berger, Mr Felix Berthold, Ms Elisa Carrari, Mr Iulian Dănilă, Mr Steffen Dietrich, Mr Raino Lievonen, Mr Francisco Rodríguez, Mr Arto Saari, Ms Iza Sondej, Mr Dawid Zieliński and Mr Jakub Zaremba for helping in field and data collection and Ms Eija Koljonen, Ms Anita Pussinen and Ms Seija Repo for processing the root samples in the Joensuu laboratory of the Natural Resources Institute Finland. We would also like to thank Mr Tapio Laakso for running the NIRS determinations of the root samples in the Vantaa laboratory of the Natural Resources Institute Finland. The research received funding from the European Union Seventh Framework Program (FP7/2007-2013) under grant agreement $\mathrm{n}^{\circ}$ 265171, FunDivEUROPE.

\section{Appendix A}

See Figs. A1-A5 and Tables A3-A8. 

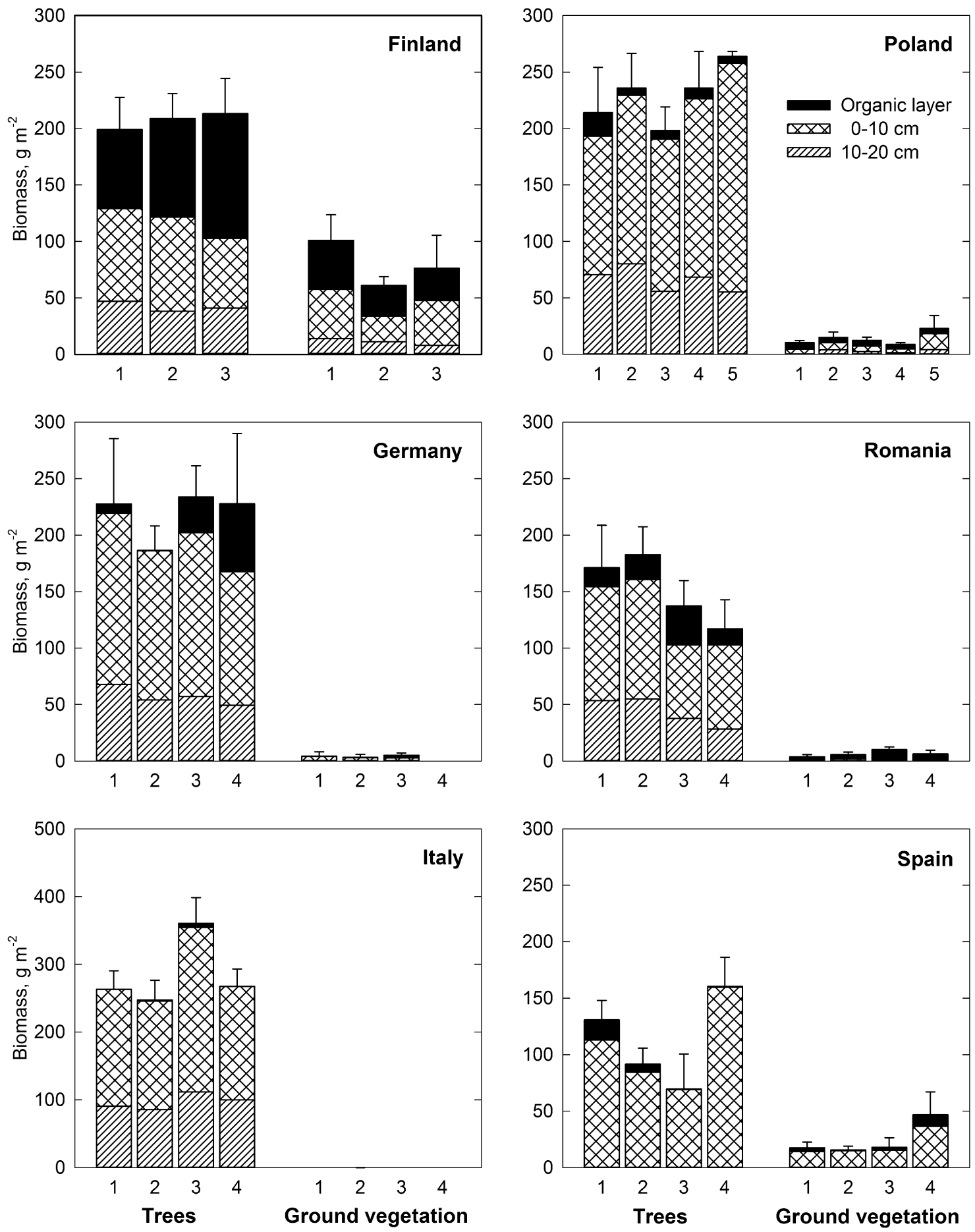

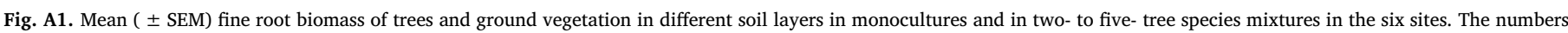
indicate the different tree species richness levels. 

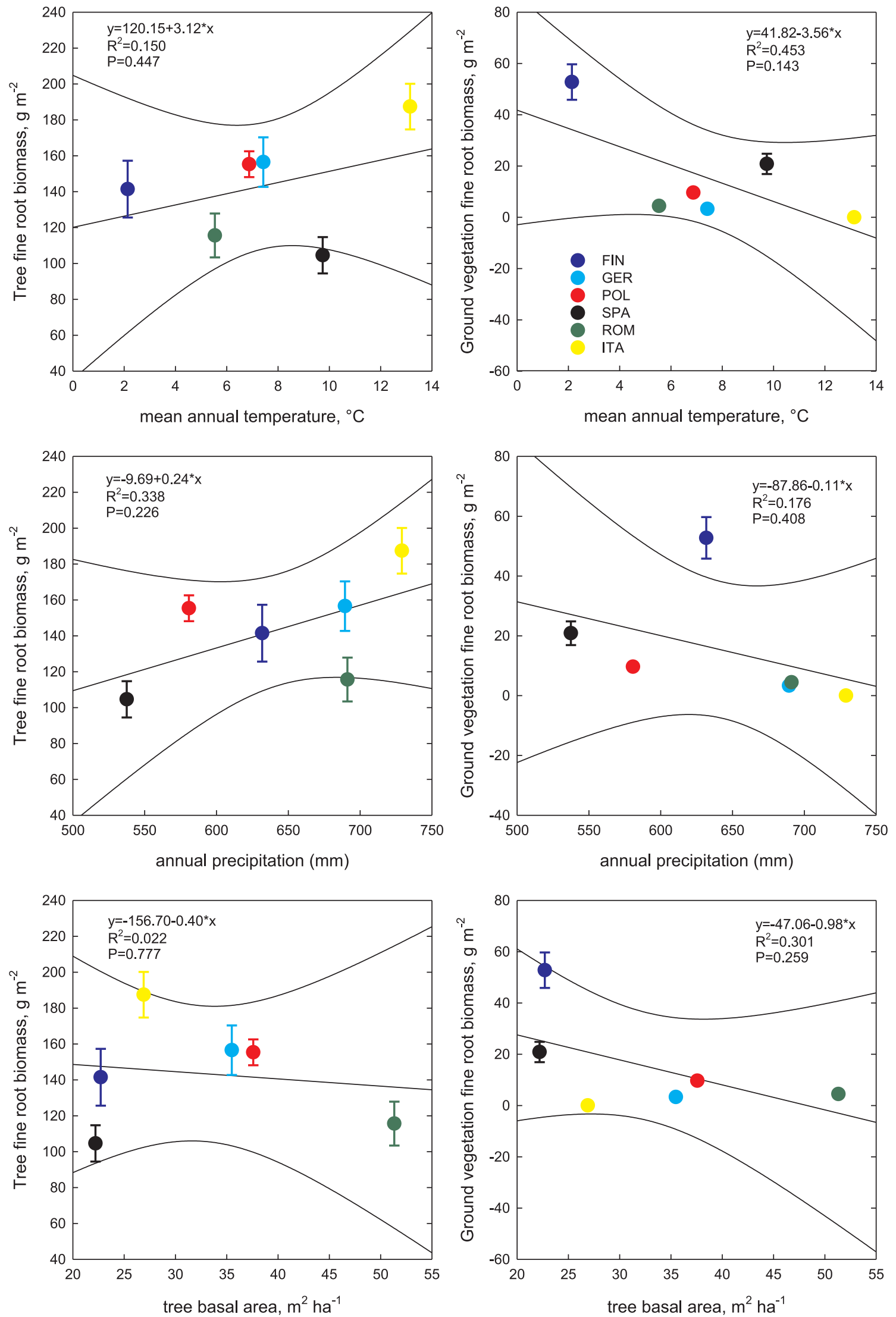

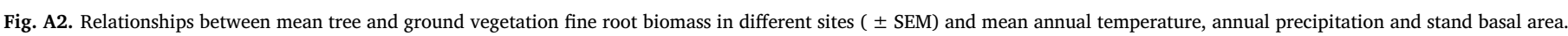
Regression lines with 95\% confidence intervals and $\mathrm{R}^{2}$ and $\mathrm{p}$-values are indicated. 

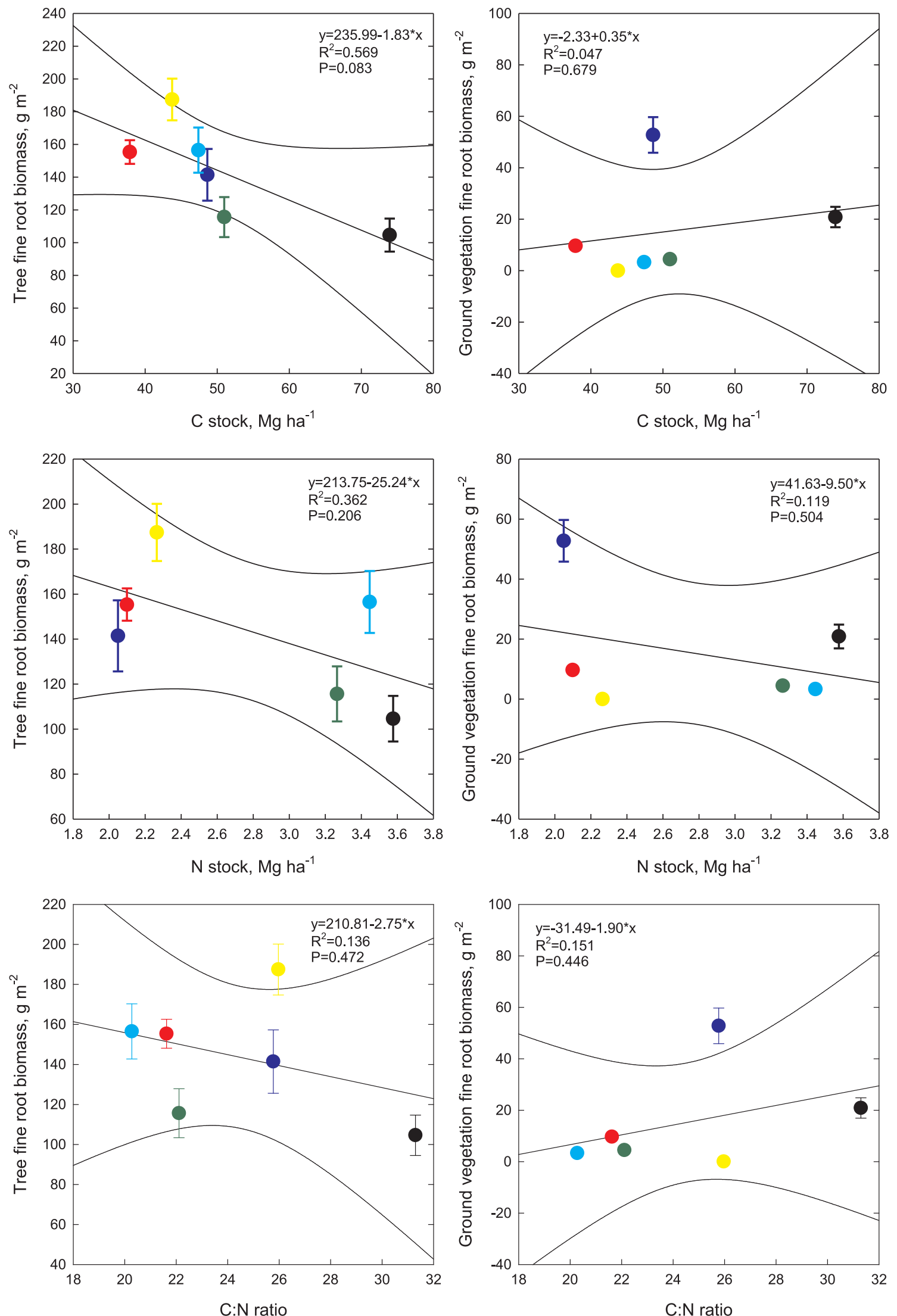

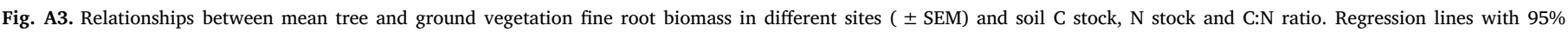
confidence intervals and $\mathrm{R}^{2}$ and $\mathrm{p}$-values are indicated. 


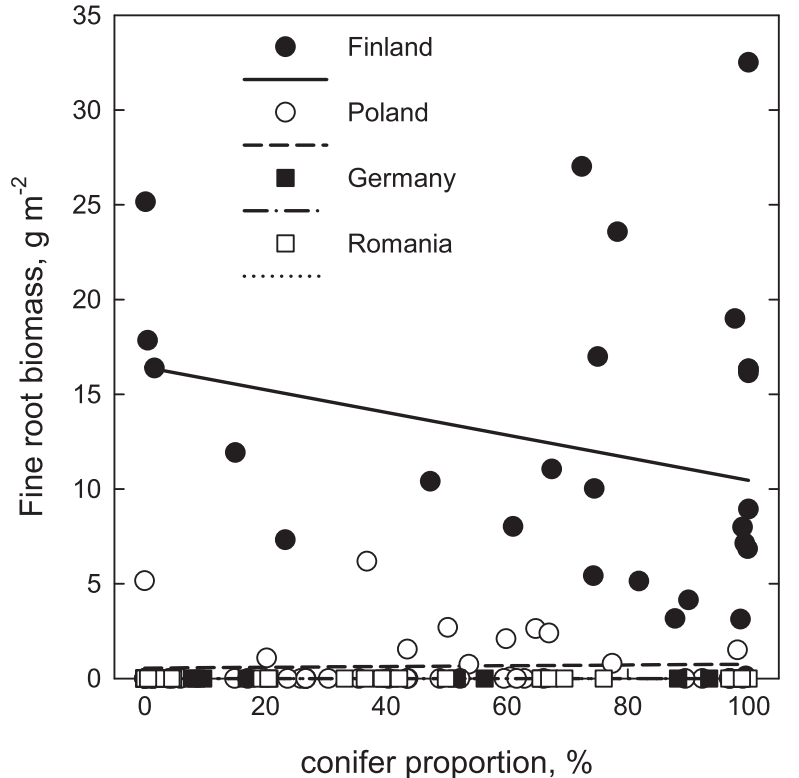

Fig. A4. Relationship between conifer proportion and ground vegetation fine root biomass in the $10-20 \mathrm{~cm}$ mineral soil in Finland, Poland, Germany and Romania. Linear regression lines are indicated, equation for Finland: $y=16.44-0.06 x, R^{2}=0.061$, $\mathrm{p}=0.207$ and for Poland: $\mathrm{y}=0.544+0.002 \mathrm{x}, \mathrm{R}^{2}=0.002, \mathrm{p}=0.776$. For Germany and Romania the relationship was constant due to zero data.
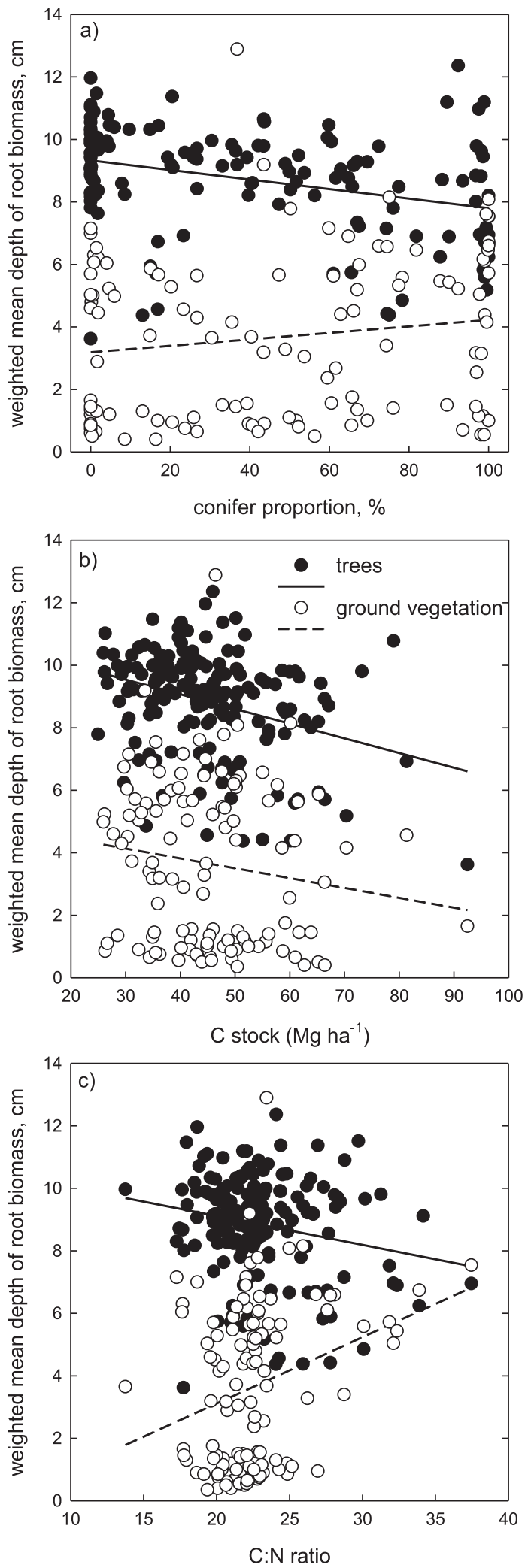

Fig. A5. Relationship between (a) conifer proportion, (b) C stock and (c) C:N ratio and the weighted mean depth of tree and ground vegetation fine root biomass. Linear regression lines are indicated. Equations in Fig. A3a for trees: $y=9.33-0.015 x, R^{2}=0.112$, $\mathrm{p}<0.001$ and for ground vegetation: $\mathrm{y}=3.19+0.01 \mathrm{x}, \mathrm{R}^{2}=0.021, \mathrm{p}=0.124$. Equations in Fig. A3b for trees: $\mathrm{y}=10.96-0.047 \mathrm{x}, \mathrm{R}^{2}=0.107, \mathrm{p}<0.001$ and for ground vegetation: $\mathrm{y}=5.08+0.032 \mathrm{x}, \mathrm{R}^{2}=0.021, \mathrm{p}=0.123$. Equations in Fig. 3Ac for trees: $\mathrm{y}=10.95-0.092 \mathrm{x}, \mathrm{R}^{2}=0.040, \mathrm{p}=0.008$ and for ground vegetation: $\mathrm{y}=1.14+0.21 \mathrm{x}$, $\mathrm{R}^{2}=0.080, \mathrm{p}=0.002$. 
Table A1

Mean depth of the organic layer and volumetric mineral soil stone content on the plots of different tree species richness levels in the six sites, and the results of mixed model.

\begin{tabular}{|c|c|c|c|c|c|c|c|c|c|c|c|c|}
\hline \multirow[b]{2}{*}{ Site } & \multicolumn{6}{|c|}{ Mean depth of organic layer by richness level, mm ( \pm SEM) } & \multicolumn{6}{|c|}{ Mean stoniness of soil by richness level, $\%$ of soil volume ( \pm SEM) } \\
\hline & 1 & 2 & 3 & 4 & 5 & Mean & 1 & 2 & 3 & 4 & 5 & Mean \\
\hline Finland & $18 \pm 5$ & $19 \pm 2$ & $21 \pm 6$ & & & $19 \pm 2$ & $31 \pm 6$ & $29 \pm 4$ & $33 \pm 3$ & & & $30 \pm 3$ \\
\hline Poland & $26 \pm 4$ & $19 \pm 2$ & $17 \pm 1$ & $18 \pm 1$ & $20 \pm 2$ & $19 \pm 1$ & $7 \pm 4$ & $5 \pm 2$ & $8 \pm 3$ & $3 \pm 1$ & $4 \pm 4$ & $6 \pm 1$ \\
\hline Germany & $15 \pm 4$ & $12 \pm 2$ & $15 \pm 2$ & $10 \pm 3$ & & $14 \pm 1$ & $21 \pm 4$ & $23 \pm 4$ & $25 \pm 5$ & $27 \pm 9$ & & $24 \pm 2$ \\
\hline Romania & $21 \pm 3$ & $20 \pm 3$ & $23 \pm 2$ & $24 \pm 7$ & & $21 \pm 2$ & $27 \pm 5$ & $29 \pm 4$ & $42 \pm 8$ & $34 \pm 22$ & & $32 \pm 3$ \\
\hline Italy & $10 \pm 2$ & $11 \pm 2$ & $14 \pm 1$ & $13 \pm 2$ & 17 & $12 \pm 1$ & $30 \pm 4$ & $28 \pm 5$ & $29 \pm 4$ & $40 \pm 6$ & 62 & $32 \pm 3$ \\
\hline Spain & $19 \pm 6$ & $11 \pm 2$ & $12 \pm 3$ & $14 \pm 2$ & & $14 \pm 2$ & $54 \pm 5$ & $57 \pm 4$ & $63 \pm 9$ & $36 \pm 5$ & & $55 \pm 3$ \\
\hline
\end{tabular}

Table A2

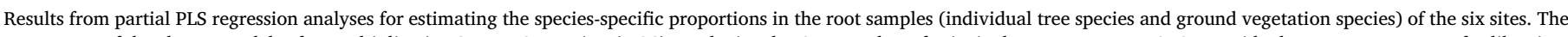

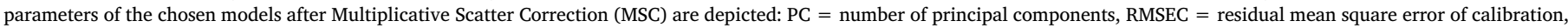
RMSEP $=$ residual mean square error of prediction, and their respective $\mathrm{R}^{2}$ values.

\begin{tabular}{|c|c|c|c|c|c|c|}
\hline Site & Tree species & PC & RMSEC & $\mathrm{R}^{2}$ & RMSEP & $\mathrm{R}^{2}$ \\
\hline \multirow[t]{4}{*}{ Finland } & Betula sp. & 5 & 4.66 & 0.98 & 3.66 & 0.98 \\
\hline & Pinus sylvestris & 5 & 6.09 & 0.96 & 6.53 & 0.95 \\
\hline & Picea abies & 6 & 5.26 & 0.97 & 5.83 & 0.96 \\
\hline & Ground veg. & 5 & 4.87 & 0.95 & 5.34 & 0.94 \\
\hline \multirow[t]{6}{*}{ Poland } & B. pendula. & 9 & 6.47 & 0.91 & 8.18 & 0.86 \\
\hline & P. sylvestris & 13 & 5.58 & 0.94 & 11.62 & 0.72 \\
\hline & P. abies & 10 & 4.43 & 0.95 & 5.88 & 0.92 \\
\hline & Quercus robur & 10 & 4.38 & 0.97 & 6.43 & 0.91 \\
\hline & Carpinus betulus & 10 & 9.88 & 0.82 & 14.2 & 0.59 \\
\hline & Ground vegetation & 8 & 5.00 & 0.88 & 5.02 & 0.92 \\
\hline \multirow[t]{6}{*}{ Germany } & Fagus sylvatica & 11 & 3.97 & 0.97 & 7.79 & 0.87 \\
\hline & Fraxinus & 11 & 3.54 & 0.97 & 6.66 & 0.91 \\
\hline & P. abies & 10 & 4.43 & 0.97 & 7.09 & 0.89 \\
\hline & Q. spp. & 8 & 3.36 & 0.98 & 4.07 & 0.97 \\
\hline & Acer pseudoplatanus & 11 & 4.35 & 0.96 & 7.89 & 0.87 \\
\hline & Ground vegetation. & 9 & 3.93 & 0.92 & 5.39 & 0.91 \\
\hline \multirow[t]{5}{*}{ Romania } & Abies alba & 7 & 5.51 & 0.94 & 5.29 & 0.90 \\
\hline & A. pseudoplatanus & 6 & 7.45 & 0.89 & 7.22 & 0.89 \\
\hline & P. abies & 7 & 8.71 & 0.84 & 8.42 & 0.86 \\
\hline & F. sylvatica & 7 & 7.39 & 0.88 & 7.73 & 0.88 \\
\hline & Ground veg. & 5 & 4.59 & 0.96 & 5.29 & 0.95 \\
\hline \multirow[t]{6}{*}{ Italy } & Q. cerris & 11 & 6.46 & 0.92 & 10.09 & 0.80 \\
\hline & Q. ilex & 7 & 8.26 & 0.86 & 8.78 & 0.84 \\
\hline & Q. petraea & 9 & 6.76 & 0.91 & 9.04 & 0.84 \\
\hline & Ostrya carpinifolia & 6 & 6.45 & 0.92 & 6.51 & 0.91 \\
\hline & Castanea sativa & 7 & 5.47 & 0.94 & 6.58 & 0.91 \\
\hline & Ground vegetation & 9 & 4.45 & 0.94 & 6.33 & 0.88 \\
\hline \multirow[t]{5}{*}{ Spain } & P. sylvestris & 10 & 9.04 & 0.84 & 13.81 & 0.62 \\
\hline & P. nigra & 12 & 6.67 & 0.90 & 13.72 & 0.63 \\
\hline & Q. ilex & 5 & 4.90 & 0.95 & 4.26 & 0.94 \\
\hline & Q. faginea & 8 & 4.14 & 0.96 & 5.87 & 0.92 \\
\hline & Ground vegetaton & 7 & 5.41 & 0.94 & 6.23 & 0.94 \\
\hline
\end{tabular}


Table A3

Results of the ANOVA tests of the multiple regression models for the effects of tree species diversity (true Shannon), conifer proportion (CP), stand basal area, C:N ratio and C stock on tree fine root biomass (a) in the organic layer, (b) in the mineral 0-10 cm soil layer, (c) in the 10-20 cm mineral soil layer and (d) in the organic $+0-10 \mathrm{~cm}$ mineral soil layer and (e) organic $+10-20 \mathrm{~cm}$ mineral soil layer. Non-significant interactions were removed.

\begin{tabular}{|c|c|c|c|c|}
\hline (a) Variables in organic layer & Df & Sum of squares & F-value & $p$-value \\
\hline Site & 1 & 4.05 & 2.67 & 0.104 \\
\hline true Shannon & 1 & 5.07 & 3.34 & 0.069 \\
\hline $\mathrm{CP}$ & 1 & 126.78 & 83.61 & $<0.001$ \\
\hline Basal area & 1 & 0.17 & 0.11 & 0.736 \\
\hline $\mathrm{C}: \mathrm{N}$ ratio & 1 & 87.63 & 57.78 & $<0.001$ \\
\hline C stock & 1 & 38.24 & 25.21 & $<0.001$ \\
\hline Residuals & 165 & 250.21 & & \\
\hline (b) Variables in $0-10 \mathrm{~cm}$ layer & Df & Sum of squares & F-value & $p$-value \\
\hline Site & 1 & 10.73 & 31.50 & $<0.001$ \\
\hline true Shannon & 1 & 0.16 & 0.46 & 0.497 \\
\hline $\mathrm{CP}$ & 1 & 0.0 & 0.0 & 0.998 \\
\hline Basal area & 1 & 0.41 & 1.19 & 0.276 \\
\hline $\mathrm{C}: \mathrm{N}$ ratio & 1 & 0.57 & 1.67 & 0.199 \\
\hline C stock & 1 & 0.77 & 2.26 & 0.276 \\
\hline Residuals & 165 & 56.52 & & \\
\hline $\begin{array}{l}\text { (c) Variables in } 10-20 \mathrm{~cm} \\
\text { layer }\end{array}$ & Df & Sum of squares & F-value & $p$-value \\
\hline Site & 1 & 4.57 & 12.16 & $<0.001$ \\
\hline true Shannon & 1 & 0.38 & 0.57 & 0.268 \\
\hline $\mathrm{CP}$ & 1 & 0.40 & 0.01 & 0.255 \\
\hline Basal area & 1 & 0.08 & 0.25 & 0.619 \\
\hline $\mathrm{C}: \mathrm{N}$ ratio & 1 & 0.14 & 0.45 & 0.504 \\
\hline C stock & 1 & 0.28 & 0.89 & 0.347 \\
\hline Residuals & 125 & 38.71 & & \\
\hline $\begin{array}{l}\text { (d) Variables in organic }+ \\
0-10 \mathrm{~cm} \text { layer }\end{array}$ & $\mathrm{Df}$ & Sum of squares & F-value & $p$-value \\
\hline Site & 1 & 3.91 & 12.16 & $<0.001$ \\
\hline true Shannon & 1 & 0.18 & 0.57 & 0.450 \\
\hline $\mathrm{CP}$ & 1 & 0.00 & 0.01 & 0.914 \\
\hline Basal area & 1 & 0.20 & 0.62 & 0.384 \\
\hline $\mathrm{C}: \mathrm{N}$ ratio & 1 & 0.03 & 0.10 & 0.748 \\
\hline C stock & 1 & 0.05 & 0.14 & 0.706 \\
\hline true Shannon * CP & 1 & 1.28 & 3.99 & 0.047 \\
\hline Residuals & 201 & 64.55 & & \\
\hline $\begin{array}{l}\text { (e) Variables in organic }+ \\
0-20 \mathrm{~cm} \text { layer }\end{array}$ & Df & Sum of squares & F-value & $p$-value \\
\hline Site & 1 & 0.07 & 0.88 & 0.350 \\
\hline true Shannon & 1 & 0.61 & 2.27 & 0.134 \\
\hline $\mathrm{CP}$ & 1 & 0.78 & 18.84 & $<0.001$ \\
\hline Basal area & 1 & 0.08 & 5.51 & 0.020 \\
\hline $\mathrm{C}: \mathrm{N}$ ratio & 1 & 1.02 & 0.47 & 0.496 \\
\hline C stock & 1 & 0.80 & 17.16 & $<0.001$ \\
\hline Residuals & 164 & 32.78 & & \\
\hline
\end{tabular}


Table A4

Results of the ANOVA tests of the multiple regression models for the effects of tree species diversity (true Shannon), conifer proportion (CP), stand basal area, C:N ratio and C stock on ground vegetation fine root biomass (a) in the organic layer, (b) in the mineral 0-10 $\mathrm{cm}$ soil layer, (c) in the $10-20 \mathrm{~cm}$ mineral soil layer and (d) in the organic $+0-10 \mathrm{~cm}$ mineral soil layer and (e) organic $+10-20 \mathrm{~cm}$ mineral soil layer. Non-significant interactions were removed

\begin{tabular}{|c|c|c|c|c|}
\hline (a) Variables in organic layer & Df & Sum of squares & F-value & $p$-value \\
\hline Site & 1 & 0.52 & 0.30 & 0.582 \\
\hline true Shannon & 1 & 0.92 & 0.59 & 0.464 \\
\hline $\mathrm{CP}$ & 1 & 27.22 & 15.94 & $<0.001$ \\
\hline Basal area & 1 & 1.15 & 0.85 & 0.359 \\
\hline C:N ratio & 1 & 64.71 & 37.89 & $<0.001$ \\
\hline C stock & 1 & 3.17 & 1.85 & 0.175 \\
\hline Residuals & 164 & 280.10 & & \\
\hline
\end{tabular}

\begin{tabular}{llll}
\hline (b) Variables in 0-10 cm layer & Df & Sum of squares & F-value \\
\hline Site & 1 & 109.27 & 90.25 \\
true Shannon & 1 & 0.01 & 0.00 \\
CP & 1 & 0.25 & 0.21 \\
Basal area & 1 & 14.57 & 12.03 \\
C:N ratio & 1 & 28.17 & 23.27 \\
C stock & 1 & 12.28 & 10.14 \\
true Shannon * CP & 1 & 5.75 & 4.75 \\
Residuals & 165 & 199.77 & 0.651 \\
\end{tabular}

\begin{tabular}{|c|c|c|c|c|}
\hline $\begin{array}{l}\text { (c) Variables in } 10-20 \mathrm{~cm} \\
\text { layer }\end{array}$ & Df & Sum of squares & F-value & $p$-value \\
\hline Site & 1 & 70.79 & 196.05 & $<0.001$ \\
\hline true Shannon & 1 & 0.27 & 0.76 & 0.385 \\
\hline $\mathrm{CP}$ & 1 & 0.13 & 0.36 & 0.558 \\
\hline Basal area & 1 & 3.67 & 10.17 & $<0.002$ \\
\hline $\mathrm{C}: \mathrm{N}$ ratio & 1 & 22.92 & 63.48 & $<0.001$ \\
\hline C stock & 1 & 1.06 & 2.94 & 0.089 \\
\hline Site * CP & 1 & 2.36 & 6.54 & 0.012 \\
\hline Residuals & 124 & 44.79 & & \\
\hline $\begin{array}{l}\text { (d) Variables in organic }+ \\
0-10 \mathrm{~cm} \text { layer }\end{array}$ & Df & Sum of squares & F-value & $p$-value \\
\hline Site & 1 & 51.28 & 26.90 & $<0.001$ \\
\hline true Shannon & 1 & 1.83 & 0.85 & 0.359 \\
\hline $\mathrm{CP}$ & 1 & 0.41 & 0.19 & 0.663 \\
\hline Basal area & 1 & 12.73 & 5.88 & 0.017 \\
\hline C:N ratio & 1 & 0.49 & 0.23 & 0.634 \\
\hline C stock & 1 & 17.07 & 7.88 & 0.006 \\
\hline Residuals & 140 & 303.3 & & \\
\hline $\begin{array}{l}\text { (e) Variables in organic }+ \\
0-20 \mathrm{~cm}\end{array}$ & Df & Sum of squares & F-value & $p$-value \\
\hline Site & 1 & 59.18 & 25.50 & $<0.001$ \\
\hline true Shannon & 1 & 5.22 & 2.45 & 0.137 \\
\hline $\mathrm{CP}$ & 1 & 0.36 & 0.15 & 0.697 \\
\hline Basal area & 1 & 5.65 & 2.44 & $<0.122$ \\
\hline $\mathrm{C}: \mathrm{N}$ ratio & 1 & 52.20 & 22.49 & $<0.001$ \\
\hline C stock & 1 & 0.40 & 0.17 & 0.678 \\
\hline Residuals & 106 & 246.00 & & \\
\hline
\end{tabular}


Table A5

Results of the ANOVA tests of the multiple regression models for the effects of tree species diversity (true Shannon), conifer proportion (CP), stand basal area, C:N ratio and C stock on total fine root biomass in the (a) organic layer, (b) 0-10 cm mineral soil layer, (c) 10-20 cm mineral soil layer, (d) organic + 0-10 cm mineral soil layer and (e) organic $+0-20 \mathrm{~cm}$ mineral soil layer. Non-significant interactions were removed.

\begin{tabular}{|c|c|c|c|c|}
\hline (a) Variables in organic layer & Df & Sum of squares & F-value & $p$-value \\
\hline Site & 1 & 0.04 & 0.03 & 0.872 \\
\hline true Shannon & 1 & 0.70 & 1.09 & 0.300 \\
\hline $\mathrm{CP}$ & 1 & 137.47 & 87.69 & $<0.001$ \\
\hline Basal area & 1 & 0.00 & 0.00 & 0.979 \\
\hline $\mathrm{C}: \mathrm{N}$ ratio & 1 & 109.63 & 69.93 & $<0.001$ \\
\hline C stock & 1 & 44.73 & 28.53 & $<0.001$ \\
\hline Residuals & 165 & 258.67 & & \\
\hline (b) Variables in $0-10 \mathrm{~cm}$ layer & Df & Sum of squares & F-value & $p$-value \\
\hline Site & 1 & 3.80 & 12.86 & $<0.001$ \\
\hline true Shannon & 1 & 0.08 & 0.27 & 0.607 \\
\hline $\mathrm{CP}$ & 1 & 0.01 & 0.02 & 0.900 \\
\hline Basal area & 1 & 0.06 & 0.19 & 0.667 \\
\hline $\mathrm{C}: \mathrm{N}$ ratio & 1 & 1.80 & 6.08 & 0.015 \\
\hline C stock & 1 & 0.05 & 0.16 & 0.689 \\
\hline Residuals & 166 & 49.14 & & \\
\hline $\begin{array}{l}\text { (c) Variables in } 10-20 \mathrm{~cm} \\
\text { layer }\end{array}$ & Df & Sum of squares & F-value & $p$-value \\
\hline Site & 1 & 1.08 & 3.59 & 0.061 \\
\hline true Shannon & 1 & 0.39 & 1.30 & 0.357 \\
\hline $\mathrm{CP}$ & 1 & 0.21 & 0.70 & 0.403 \\
\hline Basal area & 1 & 0.21 & 0.69 & 0.409 \\
\hline $\mathrm{C}: \mathrm{N}$ ratio & 1 & 0.10 & 3.33 & 0.007 \\
\hline C stock & 1 & 0.43 & 1.43 & 0.234 \\
\hline Residuals & 125 & 37.55 & & \\
\hline $\begin{array}{l}\text { (d) Variables in organic }+ \\
0-10 \mathrm{~cm} \text { layer }\end{array}$ & Df & Sum of squares & F-value & $p$-value \\
\hline Site & 1 & 0.94 & 3.11 & 0.079 \\
\hline true Shannon & 1 & 0.06 & 0.19 & 0.661 \\
\hline $\mathrm{CP}$ & 1 & 0.05 & 0.16 & 0.693 \\
\hline Basal area & 1 & 0.00 & 0.01 & 0.939 \\
\hline $\mathrm{C}: \mathrm{N}$ ratio & 1 & 0.02 & 0.07 & 0.793 \\
\hline C stock & 1 & 0.05 & 0.17 & 0.679 \\
\hline Residuals & 202 & 61.35 & & \\
\hline $\begin{array}{l}\text { (e) Variables in organic }+ \\
0-20 \mathrm{~cm} \text { layer }\end{array}$ & Df & Sum of squares & F-value & $p$-value \\
\hline Site & 1 & 0.38 & 2.08 & 0.152 \\
\hline true Shannon & 1 & 0.36 & 1.99 & 0.161 \\
\hline $\mathrm{CP}$ & 1 & 0.20 & 1.15 & 0.292 \\
\hline Basal area & 1 & 0.44 & 2.44 & 0.120 \\
\hline $\mathrm{C}: \mathrm{N}$ ratio & 1 & 1.77 & 9.78 & 0.002 \\
\hline C stock & 1 & 0.61 & 3.35 & 0.069 \\
\hline Residuals & 164 & 29.76 & & \\
\hline
\end{tabular}


Table A6

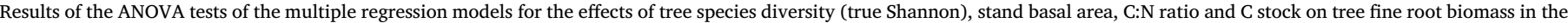
organic $+0-10 \mathrm{~cm}$ mineral soil layer for (a) pure broadleaf stands and (b) pure conifer stands. Non-significant interactions were removed.

\begin{tabular}{|c|c|c|c|c|}
\hline (a) Variables for broadleaf & Df & Sum of squares & F-value & $p$-value \\
\hline Site & 1 & 1.05 & 3.93 & 0.051 \\
\hline true Shannon & 1 & 1.90 & 7.11 & 0.009 \\
\hline Basal area & 1 & 0.13 & 0.48 & 0.490 \\
\hline $\mathrm{C}: \mathrm{N}$ ratio & 1 & 2.14 & 7.98 & 0.006 \\
\hline C stock & 1 & 0.14 & 0.53 & 0.470 \\
\hline Residuals & 84 & 22.49 & & \\
\hline (b) Variables or conifers & Df & Sum of squares & F-value & $p$-value \\
\hline Site & 1 & 0.01 & 0.05 & 0.833 \\
\hline true Shannon & 1 & 0.01 & 0.03 & 0.870 \\
\hline Basal area & 1 & 0.35 & 1.14 & 0.295 \\
\hline $\mathrm{C}: \mathrm{N}$ ratio & 1 & 0.09 & 0.28 & 0.601 \\
\hline C stock & 1 & 0.61 & 1.97 & 0.172 \\
\hline Residuals & 27 & 8.34 & & \\
\hline
\end{tabular}

Table A7

The equations for the regression lines presented in Fig. 5a-5f and the $\mathrm{R}^{2}$ and $\mathrm{p}$-values for the equations.

\begin{tabular}{|c|c|c|c|}
\hline Figure & Trees & Ground vegetation & Total \\
\hline $5 a$ & $\begin{array}{l}y=0.78+0.41 x \\
R^{2}=0.206 \\
p<0.001\end{array}$ & $\begin{array}{l}y=2.92+0.06 x \\
R^{2}=0.051 \\
p=0.003\end{array}$ & $\begin{array}{l}y=3.64+0.47 x \\
R^{2}=0.212 \\
p<0.001\end{array}$ \\
\hline $5 b$ & $\begin{array}{l}y=226.59-0.45 x \\
R^{2}=0.032 \\
p=0.019\end{array}$ & $\begin{array}{l}y=7.09+0.24 x \\
R^{2}=0.092 \\
p<0.001\end{array}$ & $\begin{array}{l}y=233.68-0.21 x \\
R^{2}=0.007 \\
p=0.270\end{array}$ \\
\hline $5 c$ & $\begin{array}{l}y=-6.29+2.73 x \\
R^{2}=0.211 \\
p<0.001\end{array}$ & $\begin{array}{l}y=1.99+0.31 x \\
R^{2}=0.033 \\
p=0.008\end{array}$ & $\begin{array}{l}y=162.04+1.08 x \\
R^{2}=0.038 \\
p=0.011\end{array}$ \\
\hline $5 d$ & $\begin{array}{l}y=155.74+0.95 x \\
R^{2}=0.029 \\
p=0.025\end{array}$ & $\begin{array}{l}y=6.29+0.13 x \\
R^{2}=0.006 \\
p=0.312\end{array}$ & $\begin{array}{l}y=162.04+1.08 x \\
R^{2}=0.038 \\
p=0.011\end{array}$ \\
\hline $5 e$ & $\begin{array}{l}y=53.25-1.15 x \\
R^{2}=0.038 \\
p=0.005\end{array}$ & $\begin{array}{l}y=11.70-0.23 x \\
R^{2}=0.032 \\
p=0.010\end{array}$ & $\begin{array}{l}64.95-1.38 x \\
R^{2}=0.046 \\
p=0.002\end{array}$ \\
\hline $5 f$ & $\begin{array}{l}y=142.32+3.65 x \\
R^{2}=0.025 \\
p=0.039\end{array}$ & $\begin{array}{l}y=-39.08+2.65 x \\
R^{2}=0.142 \\
p<0.001\end{array}$ & $\begin{array}{l}y=103.25+6.29 x \\
R^{2}=0.074 \\
p<0.001\end{array}$ \\
\hline
\end{tabular}


Table A8

Results of the ANOVA tests of the multiple regression models for the effects of tree species diversity (true Shannon), conifer proportion (CP), stand basal, C:N ratio and C stock on the mean vertical depth of (a) tree and (b) ground vegetation fine root biomass in the organic and $0-20 \mathrm{~cm}$ mineral soil layer. Nonsignificant interactions were removed.

\begin{tabular}{|c|c|c|c|c|}
\hline $\begin{array}{l}\text { (a) Variables } \\
\text { for trees }\end{array}$ & Df & Sum of squares & F-value & $p$-value \\
\hline Site & 1 & 0.73 & 22.51 & $<0.001$ \\
\hline true Shannon & 1 & 0.04 & 1.16 & 0.283 \\
\hline $\mathrm{CP}$ & 1 & 0.31 & 9.65 & 0.002 \\
\hline Basal area & 1 & 0.04 & 0.04 & 0.282 \\
\hline $\mathrm{C}: \mathrm{N}$ ratio & 1 & 0.46 & 14.13 & $<0.001$ \\
\hline C stock & 1 & 0.78 & 0.78 & $<0.001$ \\
\hline Residuals & 164 & 5.35 & & \\
\hline $\begin{array}{l}\text { (b) Variables } \\
\text { for ground } \\
\text { vegetation }\end{array}$ & Df & Sum of squares & F-value & $p$-value \\
\hline Site & 1 & 43.05 & 88.62 & $<0.001$ \\
\hline true Shannon & 1 & 0.03 & 0.06 & 0.800 \\
\hline $\mathrm{CP}$ & 1 & 0.01 & 0.01 & 0.918 \\
\hline Basal area & 1 & 0.10 & 0.21 & 0.651 \\
\hline $\mathrm{C}: \mathrm{N}$ ratio & 1 & 0.01 & 0.02 & 0.889 \\
\hline C stock & 1 & 0.34 & 0.69 & 0.408 \\
\hline Residuals & 106 & 51.49 & & \\
\hline
\end{tabular}

\section{Appendix B. Supplementary materials}

Supplementary data associated with this article can be found, in the online version, at http://dx.doi.org/10.1016/j.foreco.2017.09.017.

\section{References}

Ampoorter, E., Selvi, F., Auge, H., Baeten, L., Berger, S., Carrari, E., Coppi, A., Fotelli, M., Radoglou, K., Setiawan, N., Vanhellemont, M., Verheyen, K., 2016. Driving mechanisms of overstorey-understorey diversity relationships in European forests. Perspect. Plant Ecol. Evol. System. 19, 21-29.

Augusto, L., De Schrijver, A., Vesterdal, L., Smolander, A., Prescott, C., Ranger, J., 2015. Influences of evergreen gymnosperm and deciduous angiosperm tree species on the functioning of temperate and boreal forests. Biol. Reviewers 90, 444-466.

Bauhus, J., Khanna, P.K., Menden, N., 2000. Aboveground and belowground interactions in mixed plantations of Eucalyptus globulus and Acaria mearnsii. Can. J. For. Res. 30, 1886-1894.

Baeten, L., Verheyen, K., Wirth, C., et al., 2013. A novel comparative research platform designed to determine the functional significance of forest tree diversity in Europe. Perspect. Plant Ecol., Evol., System. 15 (5), 281-291.

Bolte, A., Villanueva, I., 2006. Interspecific competition impacts on the morphology and distribution of fine roots in European beech (Fagus sylvatica L.) and Norway spruce (Picea abies (L.) Karst.). Eur. J. Forest Res. 125, 15-26.

Brassard, B.W., Chen, H.Y.H., Bergeron, Y., Paré, D., 2011. Differences in fine root productivity between mixed- and single species stands. Funct. Ecol. 25, 238-246.

Brassard, B.W., Chen, H.Y.H., Caward, X., Laganière, J., Reigh, P.B., Bergeron, Y., Paré, D., Yuan, Z., 2013. Tree species diversity increases fine root productivity through increased soil volume filling. J. Ecol. 101, 210-219.

Bu, W.S., Schmid, B., Liu, X.J., Li, Y., Härdtle, W., von Oheimb, G., Liang, Yu., Sun, Z.K., Huang, Y.Y., Bruelheide, H., Ma, K.P., 2017. Interspecific and intraspecific variation in specific root length drives aboveground biodiversity effects in young experimental forest stands. J. Plant Ecol. 10, 158-169.

Büttner, V., Leuschner, C., 1994. Spatial and temporal patterns of fine root abundance in a mixed oak-beech forest. For. Ecol. Manage. 70, 11-21.

Chen, H.Y.H., Klinka, K., 2003. Aboveground productivity of western hemlock and western redcedar mixed-species stands in southern costal British Columbia. For. Ecol. Manage. 184, 55-64.

Clemmensen, K.E., Bahr, A., Ovaskainen, O., et al., 2013. Roots and associated fungi drive long-term carbon sequestration in boreal forest. Science 339, 1615-1618.

Cools, N., Vesterdal, L., De Vos, B., Vanguelova, E., Hansen, K., 2014. Tree species is the major factor explaining C: $\mathrm{N}$ ratios in European forest soils. For. Ecol. Manage. 311, $3-16$.

Crawley, M.J., 2012. The R Book. John Wiley \& Sons Ltd, Chichester, UK.

Dawud, S.M., Raulund-Rasmussen, K., Domisch, T., Finér, L., Jaroszewicz, B., Vesterdal, L., 2016. Is tree species diversity or species identity the more important driver of soil carbon stocks, C/N ratio and pH? Ecosystems 19, 645-660.

Dawud, S.M., Raulund-Rasmussen, K., Ratcliffe, S., Domisch, T., Finér, L., Joly, F.-X., Hättenschwiler, S., Vesterdal, L., 2017. Tree species functional group is a more important driver of soil properties than tree species diversity across major European forest types. Funct. Ecol. 31, 1153-1162.

Dixon, R.K., Brown, S., Houghton, R.A., Solomon, A.M., Texler, M.C., Wisniewski, J., 1994. Carbon pools and fluxes of global forest ecosystems. Science 263, 185-190.

Domisch, T., Finér, L., Dawud, S.M., Vesterdal, L., Raulund-Rasmussen, K., 2015. Does species richness affect fine root biomass and production in young forest plantations? Oecologia 177, 581-594.

Esbensen, K.H., 2001. Multivariate data analysis - In Practice, 5th Edition. An Introduction to Multivariate Data Analysis and Experimental Design. Camo Process AS, Oslo, Norway.

Finér, L., Helmisaari, H.-S., Lõhmus, K., et al., 2007. Variation in fine root biomass of three European tree species: Beech (Fagus sylvatica L.), Norway spruce (Picea abies L. Karst.) and Scots pine (Pinus sylvestris L.). Plant Biosyst. 141 (3), 394-405.

Finér, L., Ohashi, M., Noguchi, K., Hirano, Y., 2011. Factors causing variation in fine root biomass in forest ecosystems. For. Ecol. Manage. 261, 265-277.

Gamfeldt, L., Snäll, T., Bagchi, M., et al., 2013. Higher levels of multiple ecosystem services are found in forests with more tree species. Nature Commun. 4, 1340.

Göransson, H., Ingerslev, M., Wallander, H., 2008. The vertical distribution of $\mathrm{N}$ and $\mathrm{K}$ uptake in relation to root distribution and root uptake capacity in mature Quecus robur, Fagus sylvatica and Picea abies stands. Plant Soil 306, 129-137.

Grömping, U., 2006. Relative Importance for Linear Regression in R: The Package relaimpo. J. Stat. Softw. 17, 1-27.

Grossiord, C., Granier, A., Gessler, A., Jucker, T., Bonal, D., 2014. Does drought influence the relationship between biodiversity and ecosystem functioning in boreal forests? Ecosystems 17, 394-404.

Jackson, R.B., Canadell, J., Ehleringer, J.R., 1996. A global analysis of root distributions for terrestrial biomes. Oecologia 108, 389-411.

Jackson, R.B., Mooney, H.A., Schulze, E.E., 1997. A global budget for fine root biomass, surface area, and nutrient contents. PNAS 94, 7362-7366.

Jacob, A., Leuschner, C., Thomas, F.M., 2010. Productivity of temperate broad-leaved forest stands differing in tree species diversity. Ann. Forest Sci. 67, 503.

Jacob, A., Hertel, D., Leuschner, C., 2013. On the significance of belowground overyielding in temperate mixed forests: separating species identity and species diversity effects. Oikos 122, 463-473.

Jost, L., 2006. Entropy and diversity. Oikos 113, 363-375.

Jucker, T., Bouriaud, O., Avăcăritei, D., Coomes, D.A., 2014a. Stabilizing effects of diversity on aboveground wood production in forest ecosystem: linking patterns and processes. Ecol. Lett. 17, 1560-1569. 
Jucker, T., Bouriaud, O., Avăcăritei, D., Duduman, G., Valladares, F., Coomes, D.A., 2014b. Competition for light and water play contrasting roles in driving diversity productivity relationships in Iberian forests. J. Ecol. 102, 1202-1213.

Jucker, T., Avăcăriței, D., Bărnoaiea, I., Duduman, G., Bouriaud, O., Coomes, D.A., 2016. Climate modulates the effects of tree diversity on forest productivity. J. Ecol. 104, 388-398.

Helmisaari, H.-S., Derome, J., Nöjd, P., Kukkola, M., 2007. Fine root biomass in relation to site and stand characteristics in Norway spruce and Scots pine stands. Tree Physiol. 27, 1493-1504.

Hendricks, C.M.A., Bianchi, F.J.J.A., 1995. Root density and root biomass in pure and mixed stands of Douglas-fir and Beech. Neth. J. Agric. Sci. 43, 321-331.

Hooper, D.U., Chapin, F.S., Ewel, J.J., et al., 2005. Effects of biodiversity on ecosystem functioning: a consensus of current knowledge. Ecol. Monogr. 75, 3-35.

Kock, N., Lynn, G.S., 2012. Lateral collinearity and misleading results in variance-based SEM: an illustration and recommendations. J. Assoc. Inform. Syst. 13 (7), 546-580.

Laclau, J.P., Nouvellon, Y., Reine, C., at al, 2013. Mixing Eucaliptus and Acacia trees leads to fine root over-yielding and vertical segregation between species. Oecologia 17, 903-913.

Lehtonen, A., Palviainen, M., Ojanen, P., Kalliokoski, T., Nöjd, P., Kukkola, M., Penttilä, T., Mäkipää, R., Leppilammi-Kujansuu, J., Helmisaari, H.-S., 2016. Modelling fine root biomass of boreal tree stands using site and stand variables. For. Ecol. Manage. 359, 361-369.

Lei, P., Bauhus, J., 2010. Use of near-infrared reflectance spectroscopy to predict species composition in tree fine-root mixtures. Plant Soil 333, 93-103.

Lei, P., Scherer-Lorenzen, M., Bauhus, J., 2012a. Belowground facilitation and competition in young tree species mixtures. For. Ecol. Manage. 265, 191-200.

Lei, P., Scherer-Lorenzen, M., Bauhus, J., 2012b. The effect of tree species diversity on fine-root production in a young temperate forest. Oecologia 169, 1105-1115.

Liang, J., Crowther, T.W., Picard, N., et al., 2016. Positive biodiversity-productivity relationship predominant in global forests. Science 354 (6309). http://dx.doi.org/10. 1126/science.aaf8957.

Liu, B., Ki, H., Zhu, B., Koide, R.T., Eissenstat, D.M., Guo, D., 2015. Complementarity in nutrient foraging strategies in absorptive fine roots and arbuscular mycorrhizal fungi across 14 coexisting subtropical tree species. New Phutologist 208, 125-136.

Loreau, M., Hector, A., 2001. Partitioning selection and complementarity in biodiversity experiments. Lett. Nat. 412, 72-76.

Loreau, M., Naeem, S., Inchausti, P., et al., 2001. Biodiversity and ecosystem functioning: current knowledge and future challenges. Science 294, 804-808.

Lübbe, T., Schuldt, B., Leuschner, C., 2015. Species identity and neighbour size surpass the impact of tree sapling assemblages under dry and moist conditions. Front. Plant Sci. http://dx.doi.org/10.3389/fpls2015.00857.

Ma, Z., Chen, H.Y.H., 2017. Effects of species diversity on fine root productivity increase with stand development and associated mechanisms in a boreal forest. J. Ecol. 105, 237-245.

McCormack, M.L., Dickie, I.A., Eissenstat, D.M., et al., 2015. Redefining fine roots improves understanding of below-ground contributions to terrestrial biosphere processes. Tansley Review. New Phytol. 207, 505-518.

Meinen, C., Hertel, D., Leuschner, C., 2009a. Root growth and recovery in temperate broad-leaved forest stands differing in tree species diversity. Ecosystems 1, 1103-1116.

Meinen, C., Hertel, D., Leuschner, C., 2009b. Biomass and morphology of fine roots in temperate broad-leaved forests differing in tree species diversity: is there evidence of below-ground overyielding? Oecologia 161, 9-111.

Meinen, C., Leuschner, C., Ryan, N.T., Hertel, D., 2009c. No evidence of root system segregation and elevated fine root biomass in multi-species temperate broad-leaved forests. Trees 23, 941-950.

Ostonen, I., Lõhmus, K., Helmisaari, H.-S., Truu, J., Meel, S., 2007. Fine root morphological adaptations in Scots pine, Norway spruce and silver birch along a latitudinal gradient in boreal forests. Tree Physiol. 27, 1627-1634.

Paquette, A., Messier, C., 2011. The effect of biodiversity on tree productivity: from temperate to boreal forests. Glob. Ecol. Biogeogr. 20, 170-180.

Persson, H.A., 1983. The distribution and productivity of fine roots in boreal forests. Plant
Soil 71, 87-101.

Potter, K.M., Woodall, C.W., 2014. Does biodiversity make a difference? Relationships between species richness, evolutionary diversity, and aboveground live tree biomass. For. Ecol. Manage. 321, 117-129.

Pretsch, H., Schütze, G., 2016. Effect of tree species mixing on the size structure, density, and yield of forest stands. Eur. J. Forest Res. 135, 1-22.

Ratcliffe, S., Liebergesell, M.R., Ruiz-Benito, P., et al., 2015. Modes of functional biodiversity control on tree productivity across the European continent. Global Ecol. Biogeogr. DIU. http://dx.doi.org/10.1111/geb.12406.

R. Core Team, 2016. R: A language and environment for statistical computing. R Foundation for Statistical Computing, Vienna, Austria URL http://www.R-project.org/.

Rinnan, Å., van den Berg, F., Engelsen, S.B., 2009. Review of the most common preprocessing techniques for near-infrared spectra. Trends Anal. Chem. 28, 1201-1222.

Rothe, A., Binkley, D., 2001. Nutritional interactions in mixed species forests: a synthesis. Can. J. For. Res. 31, 1855-1870.

Scherer-Lorenzen, M., Bonilla, J.L., Potvin, C., 2007. Tree species richness affects litter production and decomposition rates in a tropical biodiversity experiment. Oikos 116, 2108-2124.

Schmid, I., 2002. The influence of soil type and interspecific competition on the fine root system of Norway spruce and European beech. Basic Appl. Ecol. 3, 339-346.

Schmid, I., Kazda, M., 2002. Root distribution of Norway spruce in monospecific and mixed stands on different soils. For. Ecol. Manage. 159, 37-47.

Shannon, C.E., 1948. A mathematical theory of communication. Bell Syst. Tech. J. 27, 379-423.

Sun, Z.K., Liu, X.J., Schmid, B., Bruelheide, H., Bu, W.S., Ma, K.P., 2017. Positive effects of tree species richness on fine-root production in a subtropical forest in SE-China. J. Plant Ecol. 10, 146-157.

Tamm, C.O., 1991. Nitrogen in Terrestrial Ecosystems: Questions of Productivity, Vegetational Changes, and Ecosystem Stability. Springer, Berlin.

Tamminen, P., Starr, M., 1994. Bulk density of forested mineral soils. Silva Fennica 28, 53-60.

Thoms, C., Gattinger, A., Jacob, M., Thomas, F.M., Gleixner, G., 2010. Direct and indirect effects of tree diversity drive soil microbial diversity in temperate deciduous forest. Soil Biol. Biochem. 42, 1558-1565.

Tobner, C.M., Paquette, A., Gravel, D., Reich, P.B., Williams, L.J., Messier, C., 2016 Functional identity is the main driver of diversity effects in young tree communities. Ecol. Lett. 19, 638-647.

Toïgo, M., Vallet, P., Perot, T., Bontemps, J.D., Piedallu, C., Courbaud, B., 2015. Overyielding in mixed forests decreases with site productivity. J. Ecol. 103, 502-512.

Vávřová, P., Stenberg, B., Karsisto, M., Kitunen, V., Tapanila, T., Laiho, R., 2008. Near Infrared Reflectance Spectroscopy for Characterization of Plant Litter Quality: Towards a Simpler Way of Predicting Carbon Turnover in Peatlands? In: Vymazal J. (ed.) Wastewater Treatment, Plant Dynamics and Management in Constructed and Natural Wetlands. Springer Science and Business Media B.V., pp. 65-87.

Vesterdal, L., Clarke, N., Sigurdsson, B.J., Gundersen, P., 2013. Do species influence soil carbon stocks in temperate and boreal forests? For. Ecol. Manage. 309, 4-18.

Vilà, M., Carillo-Gavilán, A., Vayreda, J., et al., 2013. Disentangling biodiversity and climatic determinants of wood production. PLOS ONE 8, e53530.

Viro, P.J., 1952. Kivisyyden määrittämisestä. Summary: On the determination of stoniness. Commun. Instituti Forestalis Fenniae 40(3), 23 p.

Wu, X., Wang, X., Tang, Z., Shen, Z., Zheng, C., Xia, X., Fang, J., 2015. The relationship between species richness and biomass changes from boreal to subtropical forests in China. Ecography 38, 602-613.

Zapater, M., Hossan, C., Bréda, N., Bréchet, C., Bonal, D., Granier, A., 2011. Evidence of hydraulic lift in a young beech and oak mixed forest using ${ }^{18} \mathrm{O}$ soil water labelling. Trees 25 (5), 885-894.

Zhang, Y., Chen, H.Y.H., Reich, P.B., 2012. Forest productivity increases with evenness, species richness and trait variation: a global meta-analysis. J. Ecol. 100, 742-774.

Zhang, Y., Wang, Y., Yu, S., 2014. Interspecific neighbor interactions promote the positive diversity-productivity relationships in experimental grassland communities. PLOS ONE 9 (10), e111434. http://dx.doi.org/10.1371/journal.pone.0111434. 